\title{
Kurva Phillips dan Perubahan Struktural di Indonesia : Keberadaan, Pola Pembentukan Ekspektasi, dan Linieritas ${ }^{1}$
}

\author{
Oleh: Solikin ${ }^{2}$
}

\begin{abstract}
Abstraksi
Terdapat tiga isu strategis yang menjadi pijakan penelitian empiris mengenai Kurva Phillips dalam dua dekade terakhir, yaitu: (i) apakah hubungan atau trade-off tersebut secara empiris terjadi dalam suatu perekonomian dan bagaimana hubungan atau trade-off tersebut terjadi dalam horison waktu yang berbeda? (ii) apakah hubungan atau trade-off tersebut bersifat linier (simetri) atau non linier (tidak simetri)?, dan (iii) bagaimana implikasi dari hubungan atau trade-off tersebut terhadap penerapan kebijakan ekonomi? Dengan tujuan umum untuk menjawab isu-isu strategis tersebut, fenomena Kurva Phillips akan dianalisis pada lingkup kegiatan ekonomi makro. Secara khusus, hal penting yang juga diamati adalah kemungkinan perubahan perilaku Kurva Phillips sebagai respons terhadap perubahan fundamental perekonomian, khususnya sebagai akibat krisis ekonomi 1997. Dari kajian yang dilakukan disimpulkan bahwa fenomena Kurva Phillips eksis dalam perekonomian Indonesia, dimana keberadaan dan perilaku kurva tersebut mengalami perubahan dari waktu ke waktu, sejalan dengan perubahan struktur fundamental perekonomian (regime dependent). Secara khusus, pola pembentukan ekspektasi dan linieritas dalam Kurva Phillips mengalami perbedaan (perubahan) yang signifikan antara periode pre dan pasca krisis.
\end{abstract}

1 Tulisan ini merupakan bagian dari paper penelitian dengan judul yang sama, dalam rangka pelaksanaan Program Kerja Strategis Pusat Pendidikan dan Studi Kebanksentralan (PPSK) - Bank Indonesia tahun 2003. Terima kasih disampaikan pada para peneliti di Pusat Pendidikan dan Studi Kebanksentralan, Direktorat Riset Ekonomi dan Kebijakan Moneter, dan Universitas Gajah Mada, maupun pihak-pihak lain yang terlibat dalam diskusi/seminar baik yang diadakan di Bank Indonesia maupun Universitas Gajah Mada - Yogyakarta untuk penyempurnaan draft paper penelitian ini.

2 Penulis adalah peneliti di PPSK Bank Indonesia. E-mail : solikin@ bi.go.id 


\section{Pendahuluan}

Pada umumnya, penerapan kebijakan moneter (ekonomi makro) ditujukan untuk mencapai sasaran akhir yaitu tingginya pertumbuhan output dan rendahnya laju inflasi. Salah satu fakta yang menjadi fokus perhatian sampai saat ini adalah belum terdapatnya konsensus mengenai pola hubungan antara kedua variabel tersebut. Temuan awal A.W. Phillips (1958) yang memaparkan hubungan atau trade-off antara stabilitas output dan harga menjadi salah satu topik kajian yang layak uji sampai saat ini. Hal ini terutama berkaitan dengan tiga isu strategis yang menjadi pijakan penelitian empiris dalam dua dekade terakhir, yaitu: (i) apakah hubungan atau trade-off tersebut secara empiris terjadi dalam suatu perekonomian dan bagaimana hubungan atau trade-off tersebut terjadi dalam horison waktu yang berbeda: jangka pendek dan panjang?, (ii) apakah hubungan atau trade-off tersebut bersifat linier (simetri) atau non linier (tidak simetri)?, dan (iii) bagaimana implikasi dari hubungan atau trade-off tersebut terhadap penerapan kebijakan ekonomi?

Isu pertama terlebih berkaitan dengan munculnya fakta empiris, yaitu stagflasi yang dialami oleh negara-negara industri pada tahun 1970-an, yang tentunya bertolak belakang dengan pola hubungan pada Kurva Phillips. Fakta tersebut sekaligus menunjukkan bahwa dalam jangka panjang, trade-off pada kurva Phillips hanyalah suatu ilusi. Bahkan, beberapa penelitian dalam dekade terakhir (antara lain: Fischer, 1993; Barro, 1995; Ghosh and Phillips, 1998) menyimpulkan adanya hubungan negatif yang signifikan antara pertumbuhan output dan inflasi.

Dalam konteks hubungan multivariat dimana sifat hubungan antara pertumbuhan output dan inflasi pada dasarnya sangat kompleks. Hal ini kemungkinan dikarenakan adanya pola interaksi yang variatif dan saling mempengaruhi antara determinan inflasi dan determinan pertumbuhan output. Dapat ditarik pemahaman bahwa, kalaupun hubungan erat antara inflasi dan pertumbuhan output terjadi, hubungan tersebut akan cenderung bersifat kompleks, lebih dari sekedar hubungan dua variabel yang bersifat linear dan monotonic.

Hal di atas melatarbelakangi isu kedua, yang lebih mendasarkan pada temuan Laxton et al. (1995) tentang adanya ketidaksimetrisan pengaruh kegiatan ekonomi pada inflasi pada tujuh negara utama OECD memberikan kesimpulan penting, yaitu bahwa tidak terdapat trade-off antara kegiatan ekonomi dan inflasi dalam jangka panjang. Temuan tersebut sekaligus juga mengimplikasikan bahwa terdapat bukti yang kuat bahwa Kurva Phillips adalah tidak linier. Ketidaklinieran (non-linearity) tersebut tercermin pada lebih kuatnya pengaruh shocks kelebihan permintaan (excess demand) dalam mendorong inflasi dari 
pada shocks kelebihan penawaran (excess supply) dalam meredam inflasi. Bukti yang kuat tentang adanya ketidaklinieran Kurva Phillips juga ditemukan pada hasil penelitian Clark et al. (1996), Debelle and Laxton (1997), dan Fisher et al. (1997).

Beberapa implikasi kebijakan dapat ditarik berkaitan dengan kedua isu di atas. Pertama, dengan adanya keyakinan bahwa pengaruh shocks pada sisi permintaan dan penawaran dapat diidentifikasi secara terpisah, pengambil kebijakan dapat menyelaraskan pencapaian kestabilan output dan harga dalam jangka panjang dengan lebih optimal. Hal ini antara lain dapat dilakukan melalui kebijakan pengelolaan sisi penawaran (supply-management policies), yaitu dengan mengisolir sebagian pengaruh shocks positif pada sisi penawaran sedemikian hingga pencapaian pertumbuhan output yang tinggi dalam jangka panjang tidak menimbulkan tekanan disinflationary yang pada akhirnya dapat merugikan perekonomian secara keseluruhan. Sementara itu, ketidaklinieran atau asimetri hubungan antara kegiatan ekonomi dan inflasi mempunyai implikasi penting pada kebijakan pengelolaan sisi permintaan (demand-management policies), yaitu bahwa dalam merepon shocks pada sisi permintaan, agar target inflasi yang ditetapkan dapat terealisasi, maka rata-rata output riil harus diupayakan untuk senantiasa berada di bawah level potensialnya. Konsekuensi dari kondisi tersebut adalah dalam hal output riil berada di atas tingkat potensialnya maka terdapatnya insentif bagi pengambil kebijakan untuk mempercepat respons terhadap terjadinya gejala awal inflasi, yaitu begitu terjadinya shocks positif pada permintaan aggregat. Hal ini karena untuk meredam pengaruh shocks sisi permintaan yang relatif moderat terhadap gejolak inflasi diperlukan offset yang sangat besar, yaitu berupa penurunan kegiatan ekonomi yang cukup tajam.

Beberapa studi mengenai keberadaan Kurva Phillips di Indonesia telah dilakukan dengan menggunakan pendekatan yang berbeda serta menghasilkan kesimpulan yang beragam. Umumnya, pendekatan tersebut, selain merupakan pendekatan makro yang menggunakan data agregat dan pendekatan/hipotesis tradisional, juga belum menjawab isu-isu pokok di atas secara keseluruhan, khususnya dikaitkan dengan perubahan fundamental perekonomian Indonesia pasca krisis ekonomi 1997. ${ }^{3}$ Sementara itu, dalam perspektif policy implementation, khususnya kebijakan moneter oleh Bank Indonesia, keberadan Kurva Phillips tersebut lebih diyakini sepenuhnya secara "eksogen", yaitu bahwa kebijakan pengendalian inflasi akan berdampak pada penurunan pertumbuhan ekonomi, dan

3 Salah satu hasil kajian yang pernah dilakukan, di antaranya oleh LPEM-UI menyimpulkan bahwa fenomena inflasi di Indonesia lebih merupakan fenomena struktural dan dipengaruhi oleh sisi penawaran. Hal ini berimplikasi bahwa keberadaan Kurva Phillips di Indonesia kurang begitu valid. Sri Adiningsih dari UGM menyimpulkan tentang adanya hubungan negatif antara inflasi dan pengangguran di Indonesia. Sementara itu, dari hasil kajian awal Solikin dan Anglingkusumo (1999) dari BI disimpulkan bahwa sinyalemen mengenai hubungan asimetris non-linier pada trade-off output-inflasi seperti yang diutarakan oleh Filardo (1998) juga berlaku di Indonesia. 
sebaliknya. Sejalan dengan arah kebijakan moneter ke depan yang cenderung/dapat mengarah pada penerapan kerangka kerja inflation targeting, validitas keyakinan tersebut perlu diuji lebih lanjut.

Dengan tujuan umum untuk menjawab isu-isu strategis yang terkait dengan penerapan kebijakan moneter seperti diutarakan sebelumnya, fenomena Kurva Phillips di Indonesia akan dianalisis pada lingkup kegiatan ekonomi makro. Secara khusus, penelitian akan difokuskan untuk mengkaji keberadaan Kurva Phillips, termasuk pola pembentukan ekspektasi dan linieritasnya. Hal penting yang juga diamati adalah kemungkinan perubahan perilaku Kurva Phillips sebagai responss terhadap perubahan fundamental perekonomian, khususnya sebagai akibat krisis ekonomi 1997.

Tulisan ini akan disampaikan dalam beberapa bagian. Menyambung bagian pendahuluan ini akan disampaikan fakta empiris mengenai fluktuasi output-harga dan respons kebijakan moneter di Indonesia. Selanjutnya, pada bagian tiga akan dipaparkan beberapa aspek teoritis dan permodelan, terutama terkait dengan hipotesis NewKeynesian mengenai keberadaan Kurva Phillips versi baru. Sebelum penarikan kesimpulan dan implikasi kebijakan, hasil pengujian empiris akan dikemukakan dengan mendasarkan pada penaksiran model hipotesis. Tulisan ini ditutup oleh penyampaian beberapa catatan penutup

\section{Fluktuasi Output-Harga dan Respons Kebijakan Moneter}

Fluktuasi perkembangan output an harga, sebagai indikator utama perekonomian Indonesia tidak dapat dipisahkan dari perkembangan kebijakan makro ekonomi serta kebijakan struktural di pasar keuangan yang laksanakan oleh pemerintah dan Bank Indonesia pada hampir tiga dasarwarsa terakhir. Perjalanan siklus dunia usaha (business cycle) di Indonesia mencatat peranan penting beberapa langkah kebijakan reformasi dan deregulasi di pasar keuangan, dua di antaranya yaitu Kebijakan Deregulasi 1 Juni 1983 dan Paket Kebijakan 27 Oktober 1988, dalam mempengaruhi perkembangan dan struktur perbankan, serta konsentrasi kredit. Kebijakan-kebijakan tersebut telah mengikis pembatasan akses masuk pasar dan sekaligus mendorong iklim persaingan di pasar keuangan. Selain itu, langkah deregulasi juga telah mengurangi secara siginifikan penguasaan pemerintah atas alokasi sumber daya di pasar keuangan.

Namun, di sisi lain, perkembangan di sektor keuangan yang cukup pesat tidak dapat diimbangi oleh perkembangan di sektor riil, yang pada gilirannya menyebabkan munculnya permasalahan ketidakseimbangan struktural dalam perekonomian. Selain itu, langkah reformasi dan deregulasi juga telah menyebabkan permasalahan dalam penerapan kebijakan 
moneter, terutama yang terkait dengan kestabilan perkembangan beberapa indikator moneter. Perkembangan struktural perekonomian yang tidak seimbang, yang dibarengi oleh permasalahan di sektor moneter telah menyebabkan perubahan perilaku harga dan output, terutama pada periode krisis ekonomi sejak 1997.

Sebagaimana pada Grafik 1.a dan 1.b, perilaku output dan harga menunjukkan adanya trend deterministik positif dan beberapa bentuk variasi musiman. Fenomena menarik yang dapat diamati adalah perkembangan pada tujuh tahun terakhir periode observasi, dimana krisis ekonomi 1997 telah mendorong perkembangan variabel-variabel tersebut ke arah kecenderungan fluktuasi/volatilitas yang semakin besar. Dalam periode ini, dapat diamati perkembangan output dan harga di sekitar trend (jangka panjangnya). Pada dua tahun pertama, pada saat output bergerak di atas trendnya, perkembangan harga masih berada di bawah trendnya. Namun, pada periode sejak 1997 terlihat perilaku yang berlawanan dari kedua variabel tersebut.

Grafik 1.a.

Perkembangan PDB Riil dan Trend

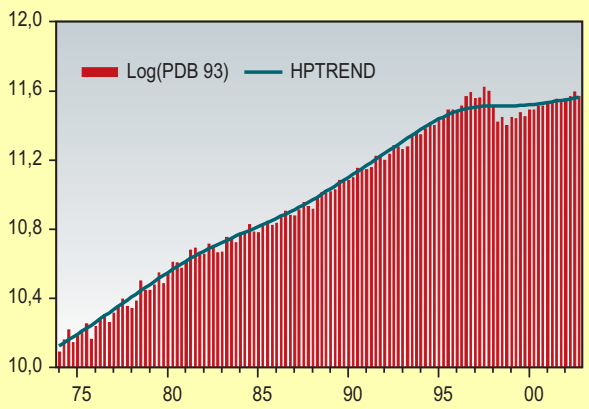

Grafik 1.b. Perkembangan Indeks Harga Konsumen (IHK) dan Trend

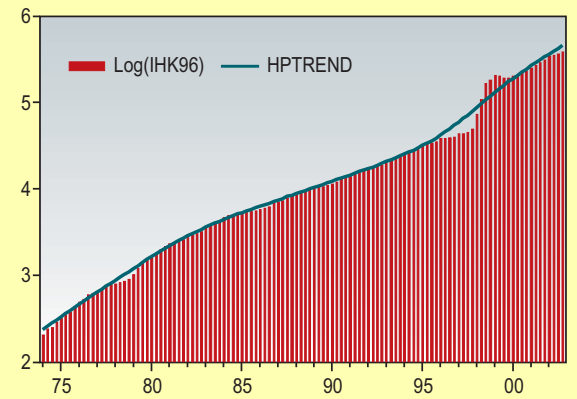

Grafik 2.

Perkembangan IHK dan Output Gap

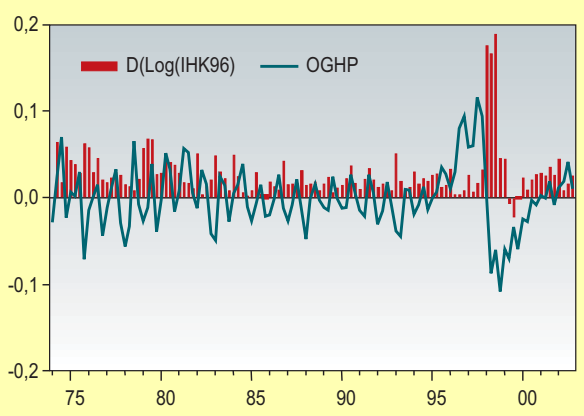




\section{Grafik 3.}

Trend Output dan harga (Normalized)

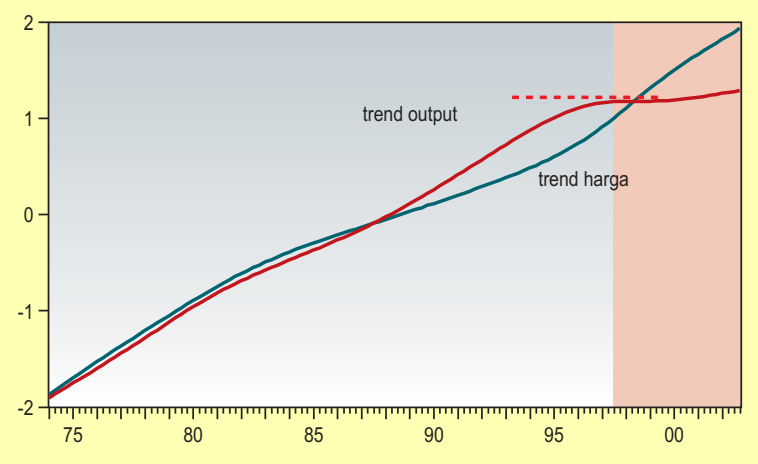

Pada Grafik 3 dapat dilihat bahwa perilaku tersebut juga tercermin pada perkembangan trend kedua variabel yang mempunyai pola yang berbeda antara periode sebelum dan sesudah 1997:2. ${ }^{4}$ Dapat diamati bahwa pada periode sebelum krisis ekonomi trend kedua variabel sama-sama menunjukkan kecenderungan positif. Namun, pada periode setelah itu, sementara slope trend perkembangan harga mempunyai kecenderungan peningkatan, trend perkembangan output terlihat cenderung melambat dengan slope mendekati nol.

Selaras dengan perkembangan perilaku di atas, Tabel 1 menunjukkan nilai moment (mean dan standard deviasi) dari output, harga, serta indikator sasaran operasional kebijakan moneter, uang primer dan suku bunga pada beberapa sub-periode observasi, yang mencerminkan adanya perubahan struktural dalam perekonomian sebagai dampak adanya reformasi dan deregulasi sektor keuangan.

4 Awal terjadinya krisis ekonomi di Indonesia diidentifikasi/diyakini pada triwulan ketiga 1997.

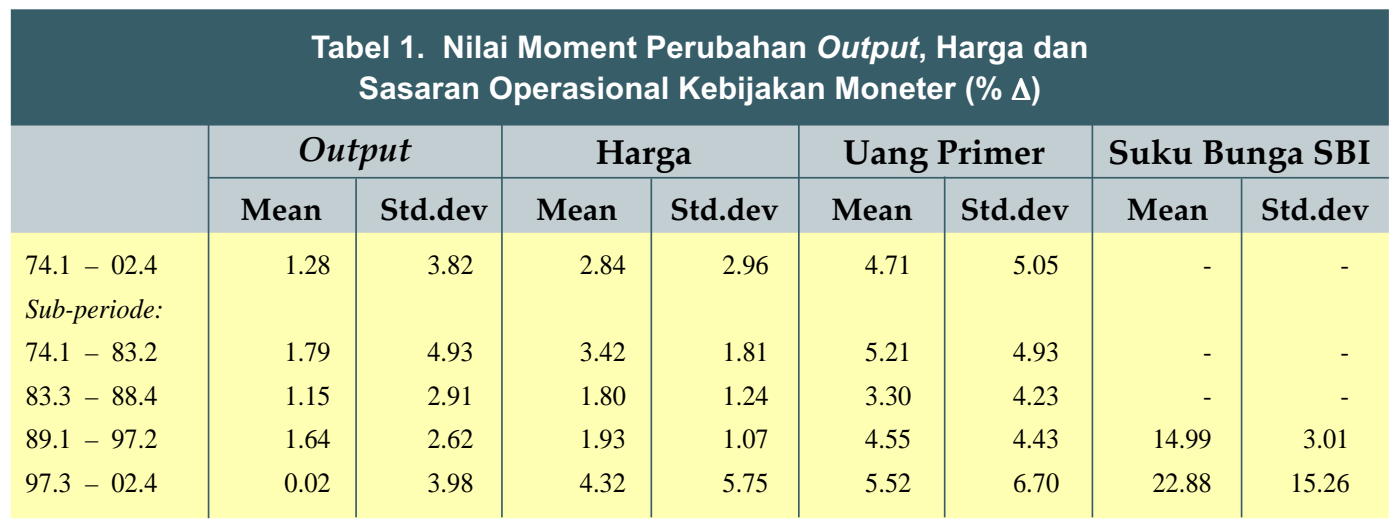


Dari tabel tersebut dapat dilihat bahwa pada tiga sub-periode pertama, perekonomian Indonesia mengalami pertumbuhan output positif (mean positif) yang signifikan, khususnya pada sub-periode pertama (rata-rata $1.79 \%$ per triwulan) dimana Indonesia mengalami keberlimpahan rezeki dari penerimaan minyak guna mendukung proses pembangunan ekonomi pada 1970-an. Namun, pengalaman krisis ekonomi yang berkepanjangan pada sub-periode terakhir telah menekan pertumbuhan ekonomi Indonesia pada tingkat yang sangat rendah, yaitu rata-rata $0.02 \%$ per triwulan. Selain itu, dapat dilihat pula bahwa perubahan struktural perekonomian sebagai akibat krisis ekonomi telah mempengaruhi kestabilan perkembangan output pada pada sub-periode ketika terjadi krisis ekonomi dunia pada awal 1980-an dan krisis ekonomi Asia 1997, yang tercermin pada relatif besarnya standard deviasi pada keua sub-periode tersebut.

Pola kecenderungan dari fluktuasi perkembangan output tersebut secara umum juga terjadi pada perkembangan harga. Pada sub-periode dimana fluktuasi perkembangan output yang relatif tinggi diimbangi oleh fluktuasi perkembangan harga yang relatif tinggi pula. Fenomena yang menarik untuk dikaji lebih lanjut terjadi pada sub-periode terakhir. Pada sub-periode (pasca) krisis ekonomi ini, berbeda perkembangan harga atau inflasi tetap tinggi, dan bahkan tertinggi (rata-rata $4.32 \%$ per triwulan), sementara perkembangan output mencapai titik terendah. Hal ini berbeda dengan pola yang terjadi pada tiga sub-periode sebelumnya ketika tingginya pertumbuhan output dibarengi oleh tingginya inflasi.

Seperti yang telah disinggung sebelumnya, perkembangan struktural perekonomian yang tidak seimbang, yang dibarengi oleh permasalahan di sektor moneter telah menyebabkan perubahan perilaku harga dan output. Apabila keterkaitan dinamis tersebut diamati lebih lanjut, permasalahan tersebut juga menyebabkan perubahan pola responss kebijakan moneter. Hal ini paling tidak dapat tercermin pada perkembangan dan volatilitas uang primer dan suku bunga yang relatif tinggi pada sub-periode terakhir.

Berdasarkan perkembangan kedua indikator sasaran operasional tersebut, paling tidak terdapat dua hal yang dapat dilihat. Pertama, pada sub-periode terakhir perkembangan uang primer, yang mencerminkan respons kebijakan moneter melalui pengendalian besaran moneter, terlihat lebih sejalan dengan perkembangan harga dibandingkan dengan perkembangan output. Kedua, sejalan dengan tingginya perkembangan uang primer, perkembangan suku bunga juga semakin tinggi. Perkembangan ekonomi dan responss kebijakan pada periode tersebut merupakan salah satu episode penting yang perlu dicermati. Seperti diketahui, pada waktu itu terjadi kelangkaan dana di perbankan sebagai akibat penarikan dana oleh masyarakat yang sangat besar. Ditambah dengan semakin melemahnya nilai rupiah terhadap dolar AS, kepercayaan masyarakat terhadap rupiah semakin melemah. 
Untuk mengatasi masalah tersebut, Pemerintah (dan Bank Indonesia) menyuntik dana ke pasar dalam jumlah yang sangat besar dalam beberapa waktu, yang selanjutnya berakibat pada melonjaknya inflasi beberapa saat kemudian. Untuk mengatasi kemungkinan terburuk selanjutnya, Bank Indonesia meningkatkan suku bunga SBI, yang selanjutnya mendorong peningkatan suku bunga pasar.

\section{Tinjauan Pustaka dan Metodologi}

\subsection{Tinjauan Pustaka tentang Kurva Phillips}

Hipotesis tingkat pengangguran alami yang dikemukanan Friedman, the natural rate hypotesis of Phillips Curve, memberikan penjelasan yang lebih memuaskan terhadap fenomena stagflasi yang dialami negara-negara industri pada tahun 1970-an. Namun, secara umum, Kurva Phillips versi tradisional dalam bentuk augmented version masih menjadi obyek kajian yang intensif dari beberapa sudut pandang. Hal ini terutama menyangkut kurangnya landasan analisis ekonomi mikro yang dalam, yang menjadikannya sebagai subyek dari kritik Lucas (Lucas critique). Lebih dari itu, validitasnya sebagai suatu building block dari model untuk evaluasi berbagai alternatif kebijakan masih dipertanyakan.

Perkembangan terkini dari teori moneter business cycle yang dikembangkan oleh ekonom New Keynessian melahirkan analisis Kurva Phillips versi baru (New Phillips Curve); disingkat KPB. KPB didasarkan pada analsis pembentukan harga nominal yang bersifat tidak kontinyu (staggered), yang diilhami oleh hasil kajian John B. Taylor (1980). Kunci perbedaan dari pendakatan ini, dibandingkan dengan Kurva Phillips versi tradisional, adalah bahwa perubahan harga merupakan hasil dari keputusan optimal dari para pelaku bisnis dalam pasar persaingan monopolistik, dengan kendala berupa frekuensi penyesuaian harga.

Spesifikasi umum dari pendekatan ini didasarkan pada model staggered price setting yang dikembangkan oleh G. Calvo (1983). Persamaan utama mengkaitkan tingkat inflasi saat ini dengan inflasi masa depan yang diharapkan dan biaya marginal:

$$
\pi_{\tau}=\beta \mathrm{E}_{\mathrm{t}}\left\{\pi_{\mathrm{t}+1}\right\}+\lambda \mathrm{mc}_{\mathrm{t}}
$$

dimana mct adalah biaya marginal riil rata-rata, dalam persentase deviasi dari level steady state, $\beta$ adalah dicount factor, dan $\lambda$ adalah koefisien yang merupakan dekomposisi dari

\footnotetext{
${ }^{5}$ Persamaan (12) diperoleh melalui agregasi dari mekanisme penentuan harga optimal dari berbagai perusahaan. Dengan meminimalkan fungsi biaya, biaya marjinal riil suatu perusahaan sama dengan tingkat upah riil dibagi dengan produk marjinal dari tenaga kerja (produktivitas tenaga kerja). Dengan asumsi bahwa perusahaan menggunakan teknologi CobDouglas, diperoleh taksiran biaya marjinal riil (rata-rata):

$\mathrm{MC}_{\mathrm{t}}=\left(\mathrm{W}_{\mathrm{t}} / \mathrm{P}_{\mathrm{t}}\right) /(1-\alpha)\left(\mathrm{Y}_{\mathrm{t}} / \mathrm{N}_{\mathrm{t}}\right)$

dimana $(1-\alpha)$ adalah parameter elastisitas tenaga kerja.
} 
beberapa parameter dalam sistem permodelan, sekaligus mencerminkan derajad kekakuan harga (price rigidity). Dalam hal ini, semakin kecil nilai I, semakin besar derajad kekakuan harga.

Dalam penurunan persaman tersebut, derajat kekakuan harga dihitung berdasarkan fraksi perusahaan yang mempertahankan harga konstan dalam tiap periode. Semakin kecil fraksi perusahaan yang melakukan penyesuaian harga, atau semakin besar fraksi perusahaan yang tidak melakukan penyesuaian harga, memyebabkan nilai $\lambda$ semakin kecil. Hal tersebut mempunyai implikasi bahwa inflasi cenderung kurang sensitif terhadap perubahan biaya marjinal.

Persamaan kedua menghubungkan biaya marginal dengan output gap. Dengan beberapa asumsi yang umumnya dipakai dalam model standar optimisasi dengan perilaku harga nominal yang kaku, pola hubungan yang sederhana antara kedua variabel tersebut dapat diturunkan sebagai berikut. ${ }^{6}$

$$
m c_{t}=\delta\left(y_{t}-y^{*}\right)
$$

dimana $\mathrm{y}_{\mathrm{t}}-\mathrm{y}^{*}{ }_{\mathrm{t}}$ masing-masing adalah logaritma dari tingkat output riil dan tingkat output alami.

Kombinasi dari (1) dan (2) menghasilkan rumusan KPB dengan dasar output gap standar: ${ }^{7}$

$$
\pi_{\mathrm{t}}=\beta \mathrm{E}_{\mathrm{t}}\left\{\pi_{\mathrm{t}}+1\right\}+\kappa\left(\mathrm{y}_{\mathrm{t}}-\mathrm{y}_{\mathrm{t}}^{*}\right)
$$

dimana $\kappa \equiv \lambda \delta$.

\section{a. Kurva Phillips Versi Baru: Hybrid Model}

Beberapa kritik ditujukan pada formulasi KPB di atas. Seperti halnya Kurva Phillips versi tradisional, inflasi diprediksi mempunyai hubungan positif terhadap tingkat output gap. Namun, dalam KPB, inflasi sepenuhnya bersifat forward looking. Dengan melakukan iterasi pada persamaan (3) diperoleh:

$$
\pi_{\mathrm{t}}=\kappa \Sigma_{\mathrm{k}=0, \infty} \beta^{\mathrm{k}} \mathrm{E}_{\mathrm{t}}\left\{\left(\mathrm{y}_{\mathrm{t}+\mathrm{k}}-\mathrm{y}_{\mathrm{t}+\mathrm{k}}^{*}\right)\right\}
$$

Dengan demikian, inflasi pada periode sebelumnya tidak relevan dalam menentukan inflasi saat ini. Hal ini berarti bahwa sepanjang bank sentral mempunyai komitmen untuk menstabilkan output gap, perekonomian dapat mencapai diinflasi dengan sendirinya tanpa

\footnotetext{
6 Lihat Rotemberg and Woodford (1997)

7 Lihat Yun (1996), Woodford (1996), dan King and Wolman (1997).
} 
suatu campur tangan bank sentral dalam mengupayakan suatu bentuk resesi ekonomi. Dengan kata lain, tidak terdapat lagi trade-off yang stabil antara harga dan output gap.

Lebih jauh, sebagaimana ditekankan oleh Fuhrer dan Moore (1995), perilaku dinamis dari inflasi dan output dalam persamaan (3) di atas terlihat janggal, apabila dikaitkan dengan bukti empiris. Persamaan tersebut mengimplikasikan bahwa inflasi mengantisipasi perkembangan output gap. Namun, bukti empiris menunjukkan hubungan yang sebaliknya: output gap cenderung mendorong terjadinya inflasi. ${ }^{8}$ Dalam kaitan tersebut, bukti empiris dirasakan konsisten dengan formulasi Kurva Phillips versi tradisional.

Sementara itu, studi terkini dari Sbordone (1999), Gali and Gertler (1999), dan Gali et al (2000) menunjukkan bukti yang signifikan dari perilaku alami inflasi yang bersifat forward-looking serta keterkaitan antara inflasi dengan biaya marjinal riil. Dengan demikian, selain menunjukkan bahwa persamaan (1) umumnya konsisten dengan data, hasil tersebut juga mendukung ide bahwa kegagalan persamaan (2) merupakan salah satu penyebab rendahnya kinerja KPB dalam menjelaskan fakta empiris.

Pertanyaan yang muncul dari beberapa fakta empiris tersebut adalah menyangkut bagaimana fenomena inflasi yang sebenarnya. Validitas dari persamaan (1) menunjukkan bahwa inflasi merupakan fenomena forward-looking. Alternatif dari rumusan tersebut adalah bahwa inflasi pada dasarnya merupakan fenomena backward-looking, sebagaimana dicerminkan oleh keterkaitan erat antara inflasi saat ini terhadap inflasi periode sebelumnya yang dipaparkan oleh analisis Kurva Phillips versi tradisional. Berkaitan dengan kedua fenomena tersebut, Gali and Gertler (1999) dan Gali et al (2000) mengajukan model gabungan/hibrid (hybrid model) dari analisis KPB, yaitu model yang juga memperhitungkan kemungkinan adanya fraksi tertentu dari perusahaan yang menggunakan pola penyesuaian backward-looking sebagai rule of thumb.

Dengan hipotesis tersebut, KPB dengan basis model hibrid dapat dituliskan sebagai:

$$
\pi_{t}=\gamma_{b} \pi_{t-1}+\gamma_{f} E_{t}\left\{\pi_{t+1}\right\}+\lambda m c_{t}
$$

,atau dengan menggunakan variabel output gap:

$$
\pi_{t}=\gamma_{b} \pi_{t-1}+\gamma_{f} E_{t}\left\{\pi_{t+1}\right\}+\kappa\left(y_{t}-y_{t}^{*}\right)
$$

,dimana $\gamma \mathrm{b}$ dan $\gamma \mathrm{f}$ masing-masing merupakan koefisien dekomposisi dari beberapa parameter dalam sistem permodelan, sekaligus mencerminkan perilaku backward-looking dan forward-looking dari inflasi.

\footnotetext{
${ }^{8}$ Paling tidak apabila digunakan log PDB yang detrended sebagai proksi dari variabel kesenjangan output.
} 
Keunggulan persamaan (5) sebagai suatu mekanisme dalam mengamati keberadaan Kurva Phillips adalah kegunaannya dalam pengujian hipotesis terhadap fenomena forwardlooking pada persamaan (1) terhadap alternatifnya, yaitu fenomena backward looking. Semakin kecil fraksi perusahaan yang melakukan penyesuaian harga secara "optimal", yaitu dengan menggunkan pola penyesuaian backward-looking sebagai rule of thumb, semakin kecil pula nilai $\gamma_{b}$. Dalam kasus dimana semua perusahaan bertindak optimal maka nilai $\gamma_{b}$ adalah nol, sehingga model berperilaku seperti pola dasar pada persamaan (1), yaitu bahwa inflasi merupakan fenomena forward-looking.

\section{b. Linieritas dan Ketidaksimetrisan dalam Kurva Phillips}

Seperti telah disinggung sebelumnya, dalam konteks hubungan multivariat dimana sifat hubungan antara pertumbuhan output dan inflasi pada dasarnya sangat kompleks. Temuan Laxton et al. (1995) menunjukkan bukti yang kuat bahwa Kurva Phillips adalah tidak linier dan tidak simetris. Ketidaklinieran (non-linearity) tersebut antara lain disebabkan oleh adanya keterbatasan kapasitas (capacity constraints) yang tercermin pada lebih kuatnya pengaruh shocks kelebihan permintaan (excess demand) dalam mendorong inflasi dari pada shocks kelebihan penawaran (excess supply) dalam meredam inflasi.

Dalan kajian lanjutan untuk kasus perekonomian Amerika Serikat, Clark et al. (1996) menangkap keberadaan ketidaksimetrisan dalam Kurva Phillips melalui aproksimasi linier terhadap fungsi konveks secara umum, yaitu melalui penggunaan asumsi bahwa pengaruh output gap positif terhadap inflasi lebih besar dibandingkan dengan pengaruh output gap negatif. Formulasi model Kurva Phillips asimetris dapat dituliskan sebagai berikut.

$$
\pi_{t}=\gamma_{f} E_{t}\left\{\pi_{t+1}\right\}+\left(1-\gamma_{f}\right) \pi_{t-1}+\beta y_{t}^{*}+\delta y p o s^{*}
$$

dimana $\mathrm{y}^{*}$ adalah level output dimana tidak terdapat kecenderungan inflasi untuk naik atau turun (dalam kondisi tidak adanya stochastic shocks dalam perekonomian, $\mathrm{y}^{\star}$ adalah output gap), sementara ypos* adalah output gap positif.

Walaupun terdapat beberapa bukti lain yang kuat tentang adanya ketidaklinieran Kurva Phillips, misalnya pada hasil penelitian Debelle and Laxton (1997), dan Fisher et al. (1997), secara teoretis, belum banyak acuan baku mengenai penetapan bentuk fungsionalnya. Dalam beberapa studi empiris alternatif spesifikasi Kurva Phillips tidak linier dapat didekati dengan beberapa cara, diantaranya yang cukup mudah adalah dengan menggunakan fungsi ekspansi pangkat berseri, fungsi kombinasi liner dan kuadratik, maupun fungsi kubik. Pendekatan yang cukup populer disampaikan oleh Chada et al. (1992) dengan menggunakan fungsi hiperbola yang dimodifikasi, yaitu: 


$$
\pi_{t}-E_{t}\left[\pi_{t+1}\right]=\beta\left[\varpi^{2} /\left(\varpi-y_{\text {gap }}\right)-\varpi\right]
$$

,dimana $\beta$ dan $\varpi$ adalah parameter yang diestimasi. $\mathrm{y}_{\text {gap }}$ adalah tingkat output gap. Slope dari trade-off antara inflasi dan aktivitas riil adalah:

$$
f^{\prime}()=\beta \varpi^{2} /\left(\varpi-y_{\text {gap }}\right)^{2}
$$

Sementara itu, dari nilai limit dari turunan tersebut adalah sebagai berikut.

limit $f^{\prime}()=\beta$

$\varpi \rightarrow \infty$

$\operatorname{limit} f^{\prime}()=\infty, f()=\infty$

$\mathrm{y}_{\mathrm{gap} \rightarrow \pi}$

$\operatorname{limit} f^{\prime}()=0, f()=-\beta \varpi$

$\mathrm{y}_{\text {gap }} \rightarrow-\infty$

$f^{\prime}(0)=\beta, f(0)=0$

Dapat dilihat bahwa pada dasarnya, $\varpi$ merupakan indeks kekurvaan (curvature); semakin besar nilainya menunjukkan Kurva Phillips yang cenderung linier. Selain itu, dari persamaan di atas dapat dilihat bahwa $\varpi$ juga merupakan pembatas dimana output gap tidak dapat meningkat dalam jangka pendek, dikarenakan adanya keterbatasan kapasitas ekonomi. Persamaan (9.c) memperlihatkan adanya batas bawah (lower bound) pada saat terjadi output gap yang semakin besar, yaitu $-\beta \varpi$. Pada saat output gap mencapai nol, pengaruhnya terhadap inflasi juga nol, dengan slope trade-off sebesar $\beta$. Secara grafis kondisis tersebut dapat diperlihatkan sebagai berikut.

\section{Grafik 4.}

Kurva Phillips

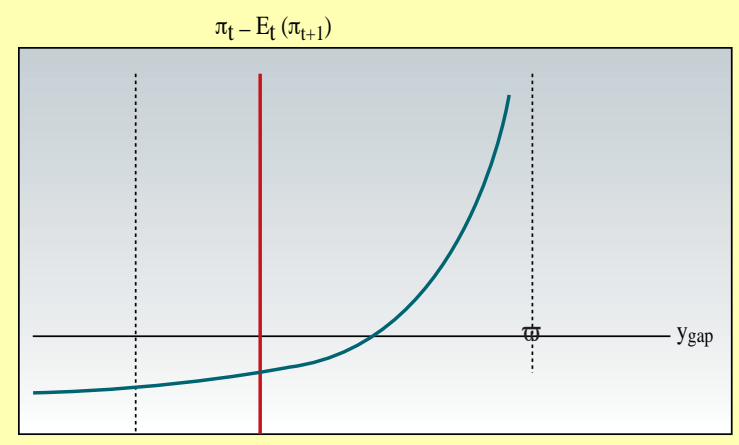


Sementara itu, Schaling (1999) dalam studinya menggunakan spesifikasi yang lebih sederhana, yaitu:

$$
E_{t}\left[\pi_{t+1}\right]-\pi_{t}=\alpha y_{t} /\left(1-\alpha \varphi y_{t}\right)
$$

, dimana a dan j adalah parameter yang diestimasi. Dengan menormalisakan tingkat output alami (asumsi tidak adanya ketidakpastian) menjadi nol, $\mathrm{y}_{\mathrm{t}}$ merupakan tingkat output gap. Dalam hal ini, j merupakan indeks kekurvaan (curvature); semakin kecil nilainya menunjukkan Kurva Phillips yang cenderung linier.

\subsection{Metodologi Penelitian}

Hipotesis penelitian ini diajukan dengan berdasarkan pada pemasalahan yang telah diuraikan dalam bagian sebelumnya. Oleh karena itu, penaksiran dilakukan secara bertahap terhadap beberapa bentuk persamaan standar Kurva Phillips, yaitu: ${ }^{9}$

\section{Uji Keberadaan}

Kurva Phillips versi tradisional (Augmented Version):

$\pi_{\mathrm{t}}=\mu+\gamma_{1} \pi_{\mathrm{t}-1}+\delta_{\mathrm{i}} \mathrm{y}_{\text {gap t-i }}+\varepsilon_{\mathrm{t}}$

dimana $\mu$ adalah konstan, dan $\gamma_{1}>0$

Apabila $\delta_{\mathrm{i}}>0$, maka keberadaan Kurva Phillips adalah valid, dalam artian terdapat hubungan positif yang signifikan antara inflasi dan output gap.

\section{Uji Keberadaan dan Pola Pembentukan Ekspektasi}

Kurva Phillips versi baru - Hybrid Model:

$\pi_{t}=\gamma_{b} \pi_{t-1}+\gamma_{f} E_{t}\left\{\pi_{t+1}\right\}+\delta_{i} y_{\text {gap t-i }}$

dimana $\delta_{i}>0$

Apabila $\gamma_{b}>0$ dan $\gamma_{f}=0$, maka pola pembentukan ekspektasi adalah backward-looking. Sebaliknya, apabila $\gamma_{b}=0$ dan $\gamma_{f}>0$, maka pola pembentukan ekspektasi adalah forward- looking. Apabila $\gamma_{b}$ dan $\gamma_{f}>0$, maka pola pembentukan ekspektasi adalah backward dan forward-looking.

\footnotetext{
${ }^{9}$ Pada umumnya, studi empiris mengenai Kurva Phillips lebih memperhitungkan variabel output gap dan ekspektasi inflasi, sementara variabel lainnya diasumsikan ceteris paribus. Hal ini terutama mengingat keberadaan Kurva Phillips tercermin dari pola hubungan antara inflasi dan output (unemployment), berbeda dengan model inflasi yang pada umumnya juga mempertimbangkan variabel-varaibel lain. Namun, tidak dapat dipungkiri, mengingat Kurva Phillips merupakan landasan permodelan inflasi, maka penaksiran Kurva Phillips dalam beberapa studi juga mempertimbangkan perananan variabel lainnya.
} 
III. Uji Keberadaan, Pola Pembentukan Ekspektasi, dan Ketidaklinieran Kurva Phillips Non-linier-backward-forward looking (Modifikasi Clark et.al.):

Kurva Phillips Konveks : $\quad \pi_{t}=\gamma_{f} E_{t}\left\{\pi_{t+1}\right\}+\gamma_{b} \pi_{t-1}+\delta_{i} y_{\text {gap t-i }}+\alpha_{j} y_{\text {gapos t-j }}$ Kurva Phillips Konkaf :

Kurva Phillips Kombinasi:

$$
\pi_{t}=\gamma_{f} E_{t}\left\{\pi_{t+1}\right\}+\gamma_{b} \pi_{t-1}+\delta_{i} y_{\text {gap t-i }}+\alpha_{k} y_{\text {gapneg } t-k}
$$

$$
\pi_{t}=\gamma_{f} E_{t}\left\{\pi_{t+1}\right\}+\gamma_{b} \pi_{t-1}+\delta_{i} y_{\text {gap t-i }}+\alpha_{j} y_{\text {gapos t-j }}+\alpha_{k} y_{\text {gapneg t-k }}
$$

, dimana $\gamma_{\mathrm{b},} \gamma_{\mathrm{f},} \delta_{\mathrm{i}}>0$

Apabila $\alpha_{j}>0$ maka terdapat "partial asymmetry" - positif-non-linearity. Apabila $\alpha_{k}<$ 0 maka terdapat "partial asymmetry" - negatif-non-linearity. Apabila $\left|\alpha_{j}\right|>\left|\alpha_{k}\right|$, maka terdapat "total asymmetry" - positif non-linearity, dan sebaliknya.

Dengan menggunakan data kuartalan (1974.1 - 2002.4), model yang diuji bervariasi mulai dari model regresi klasik sampai dengan model State-Space-Time Varying Parameter. Metode penaksiran yang akan digunakan antara lain adalah Ordinary Least Squares (OLS), Generalized Method of Moments (GMM), dan Maximum-Likelihood Estimation (MLE) Kalman Filter (KF) Algoritm.

Data yang diidentifikasi dalam penelitian ini meliputi: (i) inflasi yang diukur dengan menggunakan Indeks Harga Konsumen (IHK) tahun dasar 1996, (ii) tingkat Output, yang diukur dengan menggunakan Produk DomestikBruto (PDB) tahun dasar 1993, dan (iii) tingkat Output Potensial dan Output gap, yang diukur dengan menggunakan beberapa alternatif metode univariat, misalnya Hodrick-Prescott (HP)-Filter, Unobserved Componen (UC), dan Unobserved Componen dengan proses Markov-Switching. Sementara itu, data-data lain yang dipakai dalam analisis, termasuk di antaranya sebagai variabel instrumental, adalah uang primer, nilai tukar rupiah terhadap US dollar, dan suku bunga. Secara umum, data tersebut merupakan data skunder dan bersumber dari Badan Pusat Statistik (BPS), Bank Indonesia $(\mathrm{BI})$, dan sumber lain. ${ }^{10}$

10Data PDB riil (harga konstan atas tahun dasar) secara triwulan tersedia mulai tahun 1980. Data mulai tahun 1974 sampai dengan 1979 diperoleh melalui transformasi data tahunan menjadi triwulanan melalui metode "interpolasi deskriptif". Metode interpolasi ini dianggap lebih reprsentatif dibandingkan dengan metode interpolasi deterministik (seperti spline regression, a local quadratic polynomial, maupun metode ala Insukindro dan A.C. Diz) yang cenderung "smoother" dalam menjelaskan perilaku triwulanan PDB riil (siklikal dan musiman). Beberapa langkah dalam metode "interpolasi deskriptif" adalah sebagai berikut. Pertama, dengan mengasumsikan bahwa terdapat keterkaitan jangka panjang antara deflator PDB dengan IHK, dilakukan taksiran perubahan deflator PDB berdasarkan perubahan IHK. Kedua, melakukan taksiran PBD riil, yaitu dengan membagi PDB nominal dengan taksiran deflator PDB. Terakhir, melakukan validasi nilai taksiran perubahan triwulanan dengan menyesuaikannya terhadap restriksi perubahan tahunan. Berdasarkan metode interpolasi ini, diperoleh data triwulanan PDB riil yang mempunyai kecenderungan perubahan siklikal dan musiman yang relatif representatif, serta memenuhi kondisi dimana perubahan total selama 4 (empat) triwulan sama dengan perubahan tahunan. 


\section{Hasil Pengujian Empiris}

\subsection{Pengukuran Kesenjangan Output (Output Gap)}

Studi mengenai fluktuasi ekonomi makro membedakan antara fluktuasi jangka pendek yang bersifat siklikal dan perkembangan jangka panjang yang mencerminkan perilaku dasar dari output. Output gap umumnya didefinisikan sebagai perbedaan antara level aktual dari output dengan kecenderungan jangka panjang (trend) atau tingkat potensialnya. Dalam praktek, hampir mustahil melakukan penaksiran tingkat potensial output secara akurat. Selain itu, tidak ada prosedur baku untuk yang dapat digunakan untuk menaksir output potensial. Dalam kaitan ini, berbagai pendekatan yang dipakai umumnya menghasilkan pattern atau perubahan output potensial yang relatif sama, tetapi taksiran terhadap level seringkali berbeda tergantung pada metode yang dipilih serta asumsi yang dipakai dalam penerapan metode tersebut. Hal tersebut cukup ironis mengingat implikasi kebijakan yang ditimbulkan akan berbeda tergantung pada besar dan arah dari output potensial.

Secara umum, terdapat dua pendekatan utama dalam menaksir output potensial. Pertama, metode univariat yang mengidentifikasi output potensial semata-mata berdasarkan perilaku masa lalu dari output tanpa merujuk pada variabel-varabel ekonomi lain. Metode yang lebih bernuansa statistis dan didasarkan pada beberapa asumsi mengenai perilaku dinamis dari output ini memfokuskan pada penaksiran trend perkembangan output yang diasumsikan mendekati tingkat potensialnya. Pendekatan kedua merupakan metode multivariat yang juga memperhitungkan perkembangan variabel-veriabel ekonomi makro lain, sehingga memungkinkan perujukan pada keterkaitan antar variabel berdasarkan teori ekonomi tertentu. Dalam konteks ini, penaksiran output potensial dianggap mendekati pengertian kapasitas ekonomi atau penawaran agregat yang sustainable.

Dalam penelitian ini, kandidat metode yang akan digunakan adalah metode univariat, yang mencakup: (i) Unobserved Componen Model (UC), (ii) Unobserved Componen Markov Switching Model (UCMS), dan (iii) Hodrick-Prescott (HP) Filter. Paling tidak, terdapat empat pertimbangan utama dari pemakaian metode univariat, daripada metode multivariat, yaitu sebagi berikut. Pertama, dalam tataran teknis, metode univariat memiliki kesederhanaan konsep dibandingkan dengan metode multivariat. Demikian pula, pemakaian metode univariat akan menghindari permasalahan penggunaan restriksi/identifikasi seperti halnya dalam metode multivariat. Kedua, pada dasarnya perkembangan output potensial mencerminkan perubahan fundamental ekonomi (variabel-variabel ekonomi makro utama), sehingga pengamatan terhadap karakteristik dasar kedua variabel tersebut cukup feasible. Ketiga, tujuan penaksiran output gap adalah untuk mendapatkan suatu variabel yang dapat difungsikan sebagai variabel bebas yang dapat digunakan secara fleksibel dalam 
beragam model, baik dengan atau tanpa restriksi. Dengan demikian, metode univariat dapat mencegah permasalahan restriksi ganda.

Sementara itu, pertimbangan utama pemakaian ketiga metode univariat di atas dibandingkan dengan metode univariat lainnya adalah bahwa ketiga metode tersebut merupakan metode yang banyak diterapkan dan superior dibandingkan dengan metode penaksiran trend linier/non-linier deterministik. Uraian singkat dari masing-masing metode tersebut adalah sebagai berikut.

a. Unobserved Componen Model (Clark, 1987)

- Digunakan untuk memperoleh taksiran komponen trend jangka panjang

- Diasumsikan bahwa suatu series didekomposisikan menjadi dua komponen yang tidak dapat diamati (unobserved), yaitu Trend dan Siklus. Sistem permodelan yang ditetapkan adalah:

$Y_{t}=T_{t}+C_{t}$

$T_{t}=T_{t-1}+d_{t-1}+u_{t}$

$d_{t}=d_{t-1}+v_{t}$

$\phi(L) C_{t}=w_{t}$

$u_{t}, v_{t}, w_{t}$ bersifat independent "white noise" dengan standar deviasi masing-masing yaitu $\sigma_{u}, \sigma_{v}, \sigma_{w}$. Sementara itu, $\phi(L)$ adalah finite polinomial dengan lag operator $L$.

b. Unobserved Componen - Markov Switching Model (Hamilton, 1989), (Lam, 1990), dan (Kim, 1994)

- Digunakan untuk memperoleh taksiran komponen trend jangka panjang

- Relatif sama dengan pendekatan UC (State Space), tetapi juga memperhitungkan adanya proses perubahan yang saling berkaitan (Markov-swicthing process). Sistem permodelan yang ditetapkan adalah:

State-space model:

$y_{t}=z_{t}+n_{t}$

$n_{t}=n_{t-1}+\mu_{0}+\mu_{1} S_{t}$

$z_{t}=\phi_{1} z_{t-1}+\phi_{2} z_{t-2}+\ldots \ldots+\phi_{r} z_{t-r}+w_{t}$

$w_{t}$ bersifat independent-identically distributed (i.i.d), $\mathrm{N}\left(0, \sigma^{2}\right)$

$S_{t}=0$ atau 1 menyatakan unobserved state dari sistem. Diasumsikan bahwa transisi dari satu state ke state lainnya menganut first-order Markov process:

$\begin{array}{lll}\operatorname{Pr}\left[\mathrm{S}_{\mathrm{t}}=1 \mid \mathrm{S}_{\mathrm{t}-1}=1\right]=\mathrm{p} & ; & \operatorname{Pr}\left[\mathrm{S}_{\mathrm{t}}=0 \mid \mathrm{S}_{\mathrm{t}-1}=1\right]=1-\mathrm{p} \\ \operatorname{Pr}\left[\mathrm{S}_{\mathrm{t}}=1 \mid \mathrm{S}_{\mathrm{t}-1}=0\right]=1-\mathrm{q} & ; & \operatorname{Pr}\left[\mathrm{S}_{\mathrm{t}}=1 \mid \mathrm{S}_{\mathrm{t}-1}=1\right]=\mathrm{q}\end{array}$ 
c. Hodrick-Prescott Filter (Hodrick and Prescott, 1997)

- Digunakan untuk memperoleh taksiran komponen trend jangka panjang

- Secara teknis merupakan filter linier dua sisi (backward-forward) yang digunakan untuk menghitung smoothed-trend series (s) dari output (y) dengan cara meminimumkan loss functionl (L), yaitu varians y di sekitar nilai s, dengan penalti tertentu. $y_{t}=s_{t}+c_{t}$

$\operatorname{Min} \mathrm{L}=\sum_{t=1}^{T}\left(y_{t}-s_{t}\right)^{2}+\lambda \sum_{t=2}^{T-1}\left[\left(s_{t+1}-s_{t}\right)-\left(s_{t}-s_{t-1}\right) .\right]^{2}$

parameter penalti $\lambda$ mengontrol kemulusan series $s_{t}$. semakin besar nilail, semakin mulus perkembangan $s_{t}$. Apabila $\lambda$ mencapai nilai tak terhingga, $s_{t}$ mendekati pola trend linier. Hodrick and Prescott merekomendasikan $\lambda=1600$ untuk data kuartalan dan $\lambda=100$ untuk data tahunan.

\section{a. Hasil Penaksiran Output Gap}

Berdasarkan ketiga metode penaksiran output gap yang diajukan, diperoleh hasil penaksiran output gap, yaitu berdasarkan unobserved component model (OGUC), berdasarkan unobserved component - Markov switching model (OGMS), dan berdasarkan Hodrick-Prescott filter (OGHP). Dari grafik 14 dapat dilihat bahwa ketiga pendekatan yang dipakai umumnya menghasilkan pattern atau perubahan output potensial yang relatif sama, walaupun taksiran terhadap level-nya seringkali berbeda. Perbedaan hasil taksiran dari ketiga metode tersebut terlihat nyata pada periode paca krisis ekonomi 1997.






\section{b. Perbandingan dan Evaluasi Hasil Penaksiran}

Untuk mengetahui taksiran output gap yang representatif untuk digunakan dalam analisis dan pengujian model, perlu dilakukan perbandingan dan evaluasi terhadap masingmasing taksiran yang diperoleh dengan menggunakan metode yang berbeda. Aspek yang akan dilihat dalam hal ini adalah deskriptif statistik masing-masing taksiran output gap, korelasi linier antar output gap, dan korelasi dinamis antara output gap dengan inflasi.

\section{(i) Deskriptif Statistik}

Hasil penghitungan statistik masing-masing taksiran output gap adalah sebagai berikut.

Full sample (1974.1-2002.4)

\begin{tabular}{l|c|c|c}
\multicolumn{3}{c}{ Tabel 2. } \\
\multicolumn{3}{c}{ Hasil Penaksiran Statistik Taksiran Output Gap } \\
& OGUC & OGMS & OGHP \\
Mean & -0.000970 & -0.001967 & -0.000001 \\
Standard deviation & 0.012724 & 0.021735 & 0.036439 \\
\hline
\end{tabular}

F-test for Equal Varians (under HO: Equal Variances)

\begin{tabular}{l|l|l|}
\hline OGUC & & \\
OGMS & $2,92(0,00)$ \\
OGHP & $8,20(0,00)$ & $2,81(0,00)$
\end{tabular}

Sub-sample pre-crisis (1980.1-1997.2)

\begin{tabular}{l|c|c|c} 
& OGUC & OGMS & OGHP \\
Mean & -0.000097 & -0.001058 & -0.002528 \\
Standard deviation & 0.011688 & 0.0222218 & 0.031001 \\
\hline
\end{tabular}

\begin{tabular}{l|c|c|c}
\hline \multicolumn{3}{c}{ F-test for Equal Varians (under HO: Equal Variances) } \\
\hline OGUC & $3,61(0,00)$ & \\
OGMS & $7,04(0,00)$ & $1,95(0,00)$ & \\
OGHP & &
\end{tabular}

Sub sample post-crisis (1997.3-2002.4)

\begin{tabular}{|c|c|c|c|}
\hline & OGUC & OGMS & OGHP \\
\hline Mean & $-0,005529$ & $-0,013791$ & $-0,010800$ \\
\hline Standard deviation & 0,015960 & 0,015005 & 0,053519 \\
\hline
\end{tabular}

\begin{tabular}{l|c|c|c}
\hline \multicolumn{3}{c}{ F-test for Equal Varians (under HO: Equal Variances) } \\
\hline OGUC & $1,13(0,78)$ & \\
OGMS & $11,25(0,00)$ & $12,72(0,00)$ & \\
OGHP &
\end{tabular}


Dari tabel tersebut paling tidak dapat disimpulkan dua hal, yaitu: (i) rata-rata nilai taksiran output gap pada umumnya meningkat pada periode krisis, dan (ii) nilai varians masing-masing taksiran output gap berbeda, kecuali pada periode krisis, dimana OGUC dan OGMS mempunyai varians sama.

\section{(ii) Korelasi Linier antar output gap}

Hasil penghitungan koefisien korelasi linier antar taksiran output gap adalah sebagai berikut.

\begin{tabular}{c|c|c|c|c}
\multicolumn{5}{c}{ Tabel 3. } \\
Hasil Penaksiran Korelasi Linier \\
Periode & & OGUC & OGMS & OGHP \\
Full sample & OGUC & 1.000000 & & \\
$(\mathbf{1 9 7 4 . 1 - 2 0 0 2 . 4 )}$ & OGMS & 0.787939 & 1.000000 & \\
& OGHP & 0.569849 & 0.616014 & 1.000000 \\
\hline Sub-sample pre-crisis & OGUC & 1.000000 & & \\
$(\mathbf{1 9 8 0 . 1 - 1 9 9 7 . 2 )}$ & OGMS & 0.851627 & 1.000000 & \\
& OGHP & 0.642996 & 0.800930 & 1.000000 \\
\hline Sub-sample post-crisis & OGUC & 1.000000 & & \\
$(\mathbf{1 9 9 7 . 3 - 2 0 0 2 . 4 )}$ & OGMS & 0.629573 & 1.000000 & \\
& OGHP & 0.428384 & 0.171282 & 1.000000 \\
\end{tabular}

Dari tabel tersebut paling tidak dapat disimpulkan dua hal, yaitu: (i) terdapat korelasi yang signifikan antar taksiran output gap, dan (ii) tingkat hubungan menjadi mengecil pada periode krisis.

\section{(iii) Korelasi dinamis (output gap dan inflasi)}

Penaksiran koefisien korelasi dinamis antara output gap dan inflasi pada dasarnya dimaksudkan untuk melihat konsistensi teoretis dari hubungan output gap dan inflasi. Secara teoretis, perkembangan inflasi merespons perkembangan output gap, dalam artian peningkatan output gap akan mendorong peningkatan inflasi, dan sebaliknya. Di sisi lain, hubungan output gap dan inflasi dapat juga terjadi dari arah "kausalitas" yang sebaliknya, yaitu perkembangan inflasi akan mempengaruhi perkembangan output gap. Berbeda dengan pengaruh output gap terhadap inflasi yang bersifat searah (positif), pengaruh inflasi terhadap output gap mempunyai arah yang berlawanan (negatif). Hal ini karena peningkatan harga 
yang terjadi terus menerus pada akhirnya akan berdampak pada penurunan output riil, dan pada gilirannya mempengaruhi perkembangan output gap.

Dengan demikian, apabila perkembangan taksiran output gap bersifat mendahului (leading) perkembangan inflasi, maka koefisien korelasi dimanisnya mempunyai arah positif. Sebaliknya, apabila perkembangan taksiran output gap bersifat mengikuti (lagging) perkembangan inflasi, maka koefisien korelasi dimanisnya mempunyai arah negatif. Hasil penghitungan koefisien korelasi dinamis antara taksiran output gap dengan inflasi adalah sebagai berikut.

Full sample (1974.1-2002.4)

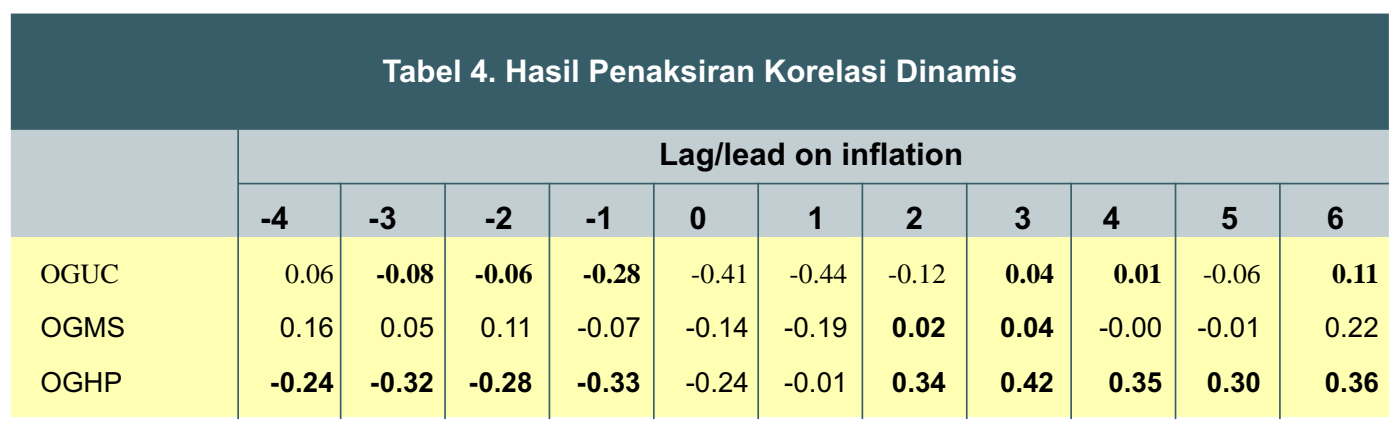

Sub-sample pre-crisis (1980.1-1997.2)

\begin{tabular}{l|c|c|c|c|c|c|r|r|r}
\multicolumn{1}{c|}{} & \multicolumn{10}{c}{ Lag/lead on inflation } \\
\cline { 2 - 9 } & $\mathbf{- 4}$ & $\mathbf{- 3}$ & $\mathbf{- 2}$ & $\mathbf{- 1}$ & $\mathbf{0}$ & $\mathbf{1}$ & $\mathbf{2}$ & $\mathbf{3}$ & $\mathbf{4}$ \\
OGUC & 0,01 & 0,00 & 0,08 & 0,13 & $-0,08$ & $-0,14$ & 0,07 & 0,20 & $-0,01$ \\
OGMS & 0,25 & 0,11 & 0,22 & 0,15 & 0,08 & 0,04 & 0,20 & 0,25 & $-0,01$ \\
& $-0,03$ & $-0,04$ & $-0,01$ & 0,02 & $-0,19$ & $-0,10$ & 0,09 & 0,19 & $-0,10$
\end{tabular}

Sub sample post-crisis (1997.3-2002.4)

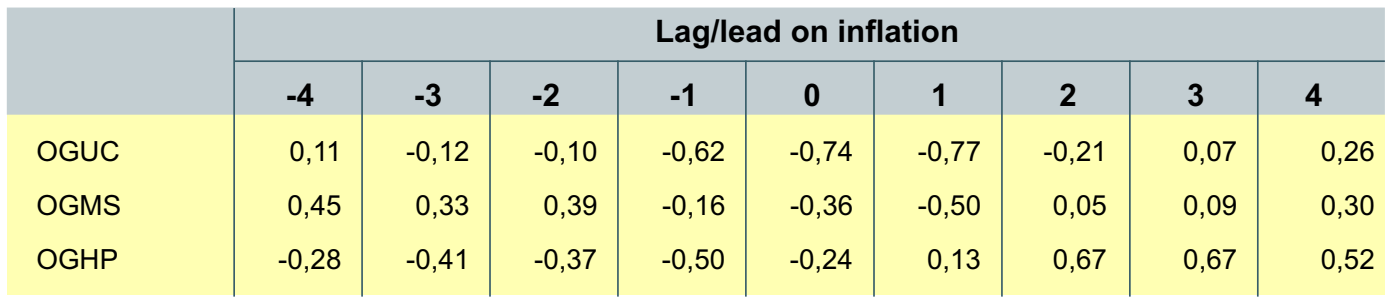

Dari tabel tersebut dapat disimpulkan beberapa hal, yaitu: (i) secara keseluruhan, terdapat superioritas dari OGHP pada ragam periode sampling yang berbeda, (ii) OGUC lebih superior dari OGMS, dan (iii) untuk periode pre-krisis, baik OGMS dan OGUC dapat dijadikan alternatif disamping OGHP. 


\subsection{Pengujian Model Empiris}

Sebagaimana hipotesis yang diajukan sebelumnya, pengujian model empiris dilakukan melalui penaksiran model secara bertahap, yaitu: (i) uji keberadaan, (ii) uji keberadaan dan pola pembentukan ekspektasi, dan (iii) uji keberadaan, pola pembentukan ekspektasi, dan linieritas. Dengan mempertimbangkan derajad kekompleksan fenomena Kurva Phillips, uji keberadaan merupakan uji persyaratan minimal yang harus dipenuhi. Untuk menguji keberadaan digunakan model hipotesis Kurva Phillips tradisional (Augmented Phillips Curve). Secara tersirat, dengan disain model yang memperhitungkan nilai masa lalu dari inflasi tersebut, terkandung makna bahwa perilaku Kurva Phillips bersifat bakward-looking. Derajad kekompleksan yang lebih tinggi dari fenomena Kurva Phillips dikaji dengan melihat pula bagaimana pola pembentukan ekspektasi pasar secara utuh, apakah backward-looking, forward-looking, atau kedua-duanya. Untuk menguji hal tersebut digunakan model hipotesis Kurva Phillips baru, yaitu model hybrid. Selanjutnya, derajad kekompleksan yang tertinggi dari fenomena Kurva Phillips dikaji dengan melihat tidak hanya keberadaan dan pola pembentukan ekspektasi pasar secara utuh, namun juga adanya kemungkinan bahwa perilaku Kurva Phillips bersifat non-linier/asimetri. Untuk menguji hal tersebut digunakan model hipotesis Kurva Phillips modifikasi Clark, et al., (1995), yaitu model yang memperhitungkan semua kemungkinan terbentuknya Kurva Phillips yang bersifat non-linier.

Kerangka pengujian tersebut dilengkapi pula dengan pembandingan hasil pengujian pada sub-sampel yang berbeda, yaitu pada periode sebelum dan sesudah terjadinya krisis ekonomi 1997 (pre and post-crisis). Perbandingan hasil ini perlu dilakukan mengingat terjadinya perubahan fundamental ekonomi dan keterkaitan antar variabel pada periode sesudah krisis 1997.

Data utama yang digunakan dalam pengujian model adalah inflasi headline (IHK tahun dasar 1996) dan output gap yang merupakan selisih antara output riil (PDB harga konstan 1993) dengan tingkat potensialnya yang diperoleh berdasarkan metode filtrasi backward-forward Hodrick-Prescott. Dalam konteks empiris, variabel tingkat kesempatan kerja (unemployment) juga merupakan variabel yang banyak digunakan, selain data perkembangan output riil. Penelitian ini menggunakan data variabel perkembangan output riil dengan paling tidak dua pertimbangan sebagai berikut. Pertama, data tingkat kesempatan kerja di Indonesia tersedia dalam bentuk tahunan, sehingga jumlah obeservasi yang akan digunakan dalam penaksiran model kurang mencukupi, dibandingkan dengan data utput riil yang dapat diperoleh dalam bentuk triwulanan dan time-frame yang lebih panjang. Kedua, dalam kaitannya dengan penerapan kebijakan moneter, khususnya di 
Indonesia, keterkaitan variabel harga-output dianggap lebih strategis dibandingkan dengan keterkaitan variabel harga-pengangguran, ataupun upah-pengangguran.

\subsubsection{Uji Keberadaan}

Uji keberadaan Kurva Phillips dilakukan dengan melakukan penaksiran model:

$$
\pi_{t}=\mu+\gamma \pi_{t-1}+\delta y_{\text {gap t-i }}+\varepsilon_{t}
$$

, dimana $p_{t}(D \log (I H K))$ adalah inflasi periode saat ini $(t), p_{t-1}$ adalah inflasi satu periode sebelumnya, $\mathrm{y}_{\text {gap t-i }}$ adalah output gap pada periode sebelumnya, dan $\varepsilon$ adalah residual.

Sebagaimana karakteristik model regresi linier klasik pada umumnya, model tersebut dapat ditaksir dengan menggunakan metode OLS. Pengaruh output gap (dalam transformasi bentuk log) terhadap inflasi ditaksir dengan memperhitungkan keterkaitan antar variabel dengan panjang lag antara 1 sampai dengan 4 triwulan. Sejalan dengan itu, kriteria model terbaik dipilih dengan berdasarkan pada kesesuaian arah dan tingkat signifikasi pengaruh masing-masing variabel bebas. Selain itu, evaluasi juga dilakukan untuk melihat otokorelasi pada perilaku residual. Hasil penaksiran dengan menggunakan data triwulanan pada beberapa periode yang berbeda dirangkum pada tabel 5 berikut.

\begin{tabular}{|c|c|c|c|c|}
\hline \multicolumn{5}{|c|}{$\begin{array}{c}\text { Tabel } 5 . \\
\text { Hasil Uji Keberadaan Kurva Phillips }\end{array}$} \\
\hline Periode & $\gamma$ & $\delta$ & $\mathbf{R}^{2}$ & $\underset{\left({ }^{*}\right)}{\text { ARCH LM-test }}$ \\
\hline $\begin{array}{l}\text { Full sample } \\
(1974.1-2002.4)\end{array}$ & $\begin{array}{c}0.602 \\
(8.886)\end{array}$ & $\begin{array}{c}0.288 \\
(5.236)\end{array}$ & 0.486 & $\begin{array}{c}0.478 \\
(1)\end{array}$ \\
\hline $\begin{array}{l}\text { Sub-sample pre-crisis } \\
\quad(1980.1-1997.2)\end{array}$ & $\begin{array}{c}0.354 \\
(3.604)\end{array}$ & $\begin{array}{l}0.245^{* *} \\
(1.857)\end{array}$ & 0.166 & $\begin{array}{c}0.230 \\
(4)\end{array}$ \\
\hline $\begin{array}{l}\text { Sub-sample post-crisis } \\
(1997.3-2002.4)\end{array}$ & $\begin{array}{c}0.603 \\
(5.111)\end{array}$ & $\begin{array}{c}0.570 \\
(4.692)\end{array}$ & 0.733 & $\begin{array}{c}0.060 \\
(4)\end{array}$ \\
\hline \multicolumn{5}{|c|}{$\begin{array}{l}\text { Keterangan: } \\
\left.\text { Angka dalam kurung di bawah masing-masing parameter adalah nilai statistik-t. ARCH LM-test( }{ }^{*}\right) \text { adalah uji residual dengan lag otoregresif } \\
\text { antara } 1 \text { sampai } 4 \text { periode. Subscipt i merupakan periode lag dari pengaruh output gap (OGHP) pada inflasi, yaitu sekitar } 2 \text { periode. } \\
\text { **) parameter ditaksir dengan menggunakan output gap berdasarkan metode unobserved component (OGUC) dengan pengaruh lag } 3 \text { periode. }\end{array}$} \\
\hline
\end{tabular}


Berdasarkan hasil penaksiran pada tabel tersebut dapat dilihat bahwa secara keseluruhan model dapat menjelaskan perilaku Kurva Phillips versi tradisional. Selain pengaruh variabel bebas yang signifikan pada level $5 \%$, uji residual menunjukkan bahwa perilaku residual tidak mengandung otokorelasi. Secara keseluruhan (full sample), parameter regresi dari lag inflasi, parameter backward looking, (0.60) dan output gap (0.29) adalah sangat signifikan.

Lebih jauh, dari hasil tersebut dapat dilihat pula bahwa pengaruh output gap terhadap inflasi mengalami perubahan dari 0.25 pada periode sebelum krisis menjadi 0.57 pada periode pasca krisis. Hal ini menunjukkan bahwa pada periode pasca krisis terjadi peningkatan pengaruh /tekanan kegiatan enonomi riil pada perkembangan harga. Selain menyebabkan peningkatan slope Kurva Phillips, perubahan tersebut juga mengimplikasikan bahwa pada masa krisis rigitas perkembangan harga dalam meresponss perkembangan sisis permintaan mengalami penurunan. Secara keseluruhan, hasil tersebut menyimpulkan bahwa keberadaan Kurva Phillips di Indonesia dengan hipotesis pembentukan ekspektasi backward-looking adalah valid.

\subsubsection{Uji Keberadaan dan Pola Pembentukan Ekspektasi}

Uji keberadaan dan pola pembentukan ekspektasi Kurva Phillips dilakukan dengan melakukan penaksiran model:

$\pi_{t}=\gamma_{b} \pi_{t-1}+\gamma_{f} E_{t}\left\{\pi_{t+1}\right\}+\delta y_{\text {gap t-i }}$

atau

$\pi_{t}=\gamma_{b} \pi_{t-1}+\gamma_{f} \pi_{t+1}+\delta y_{\text {gap t-i }}+\varepsilon_{t}^{e}$

, dimana $\pi_{\mathrm{t}+1}$ adalah realisasi inflasi satu periode mendatang dan $\varepsilon^{\mathrm{e}}{ }_{\mathrm{t}}$ adalah expectational error. Berdasarkan hipotesis asa nalar (rational expectation), residu tersebut tidak dapat ditaksir (unforecastable) pada periode $t$, sehingga parameter forward-looking, $\mathrm{g}_{\mathrm{f}}$, dapat secara konsisten ditaksir dengan menggunakan nilai variabel pada periode saat ini $(\mathrm{t})$ atau lebih awal sebagai instrumen dari $\pi_{\mathrm{t}+1}{ }^{11}$ Dengan struktur model tersebut, metode penaksiran

${ }^{11}$ Secara umum, spesifikasi persamaan tersebut untuk pengujian empiris kasus Indonesia cukup relevan mengingat dalam perkembangan ekonomi, sosial, budaya, dan politik di Indonesia dewasa ini memungkinkan agen ekonomi untuk "berpresepsi" baik secara backward maupun forward. Selain itu, validitas penggunaan asumsi rational expectation dalam penaksiran model empiris di Indonesia dianggap cukup memadai, walaupun tidak sepenuhnya. Paling tidak, walaupun tidak mencapai kadar "optimalisasi" pengelolaan informasi yang sempurna (yang dalam praktek tidak dijumpai), agen ekonomi dapat memperhitungkan beberapa informasi yang terkait dengan perkembangan beberapa indikator makro, baik yang terjadi pada masa lalu dan saat ini, maupun gambaran prospek ke depan.

Parkin and Bade (1988) dalam bukunya Modern Macroeconomics mengemukakan bahwa ekspektasi pada dasarnya mempunyai dua bentuk yang berbeda, yaitu subjective expectation (SE) dan conditional mathematical expectation (CME). 
dengan menggunakan OLS tidak dapat digunakan, dan sebagai gantinya yang umum digunakan adalah GMM. ${ }^{12}$ Variabel instrumental yang digunakan dalam penaksiran adalah inflasi (lag 1 dan 2), perubahan nilai tukar (lag 0 dan 1), pertumbuhan uang primer (lag 0 dan 1), faktor musiman, dan konstan.

Hasil penaksiran dirangkum pada Tabel 6. Berdasarkan hasil penaksiran tersebut dapat dilihat bahwa secara keseluruhan model dapat menjelaskan perilaku Kurva Phillips versi baru. Selain pengaruh variabel bebas yang signifikan pada level 10 , dan bahkan $5 \%$, uji residual menunjukkan bahwa perilaku residual tidak mengandung otokorelasi. Berbeda dengan bentuk standar statistik yang digunakan dalam evaluasi model, misalnya $\mathrm{R}^{2}$, GMM menghitung nilai statistik-j, yaitu nilai minimum dari fungsi objective. Statistik-j dapat digunakan untuk menguji hipotesis dari hasil penaksiran GMM, antara lain pengujian validitas penggunaan variabel instumental yang jumlahnya melebihi jumlah parameter yang ditaksir (overidentifying restrictions). Dari hasil pengujian secara terpisah, disimpulkan bahwa kondisi overidentifying restrictions pada penaksiran model tersebut valid.

Secara keseluruhan (full sample), baik parameter backward maupun forward looking dan output gap (0.22) sangat signifikan secara statistik. Terlihat bahwa, berdasarkan struktur model di atas, nilai $\gamma_{f}$ secara signifikan lebih besar dari $\gamma_{b}$, yang mengindikasikan dominasi Kuva Phillips New-Keynesian dalam menjelaskan proses inflasi. Selain itu, uji restriksi parameter Wald menyimpulkan bahwa jumlah parameter backward dan forward looking adalah satu. ${ }^{13}$ Lebih jauh, dari hasil tersebut dapat dilihat pula bahwa pengaruh output gap terhadap inflasi mengalami perubahan walaupun tidak signifikan, yaitu dari 0.10 pada periode sebelum krisis menjadi 0.12 pada periode pasca krisis. Secara keseluruhan, hasil tersebut menyimpulkan bahwa keberadaan Kurva Phillips di Indonesia dengan hipotesis pembentukan ekspektasi hybrid adalah valid.

SE pada dasarnya lebih menggambarkan penilaian atau semacam "vague feeling" mengenai sesuatu kejadian yang akan terjadi, yang umumnya tanpa dilandasi oleh analisis yang eksplisit terhadap alasan yang melatarbelakangi ekspektasi tersebut. Sementara itu, CME merupakan ekspektasi matematis yang dihitung berdasarkan beberapa informasi yang didapatkan, yang pada umumnya lebih "bernuansa" perkiraan rata-rata. Dari dua bentuk ekspektasi tersebut, berkembanglah ide ekspektasi yang rasional (rational expectation - RE) sebagaimana dikemukakan pertama kali oleh John F. Muth (1961) dan selanjutnya dipopulerkan dalam kancah ilmu ekonomi makro oleh Robert E. Lucas Jr. (1973), yaitu bahwa “An expectation is said to be rational when the subjective expectation coincides with the conditional mathematical expectation based on all available information.".

Dalam kasus pembentukan harga, apakah informasi itu hanya berupa perkembangan harga pada periode-periode sebelumnya, ataupun ditambah dengan perkembangan nilai tukar dan uang beredar, maupun "persepsi" mengenai prospek ekonomi di masa mendatang, semuanya itu merupakan pijakan yang relevan yang dapat digunakan dalam membentuk perilaku yang "rasional".

${ }^{12}$ Generalized Method of Moments (GMM) adalah metode penaksiran yang merupakan robust esrimator, dengan prinsip melakukan pemilihan nilai taksiran parameter (parameter estimate) agar moments dari sampel selaras dengan moments dari populasi, yaitu sama dengan nol. Dengan demikikian, keterkaitan teoritis yang disyaratkan adalah adanya kondisi ortogonalitas (orthogonality conditions) antara suatu fungsi dari parameter, linier atau non-linier, dengan kumpulan variabel instrumental (instrumental variables). Berbeda dengan metode penaksiran OLS dan MLE, GMM tidak menyaratkan adanya informasi mengenai bentuk distribusi dari residual. Selain itu, metode penaksiran pada umumnya merupakan kasus spesial dari GMM. 


\begin{tabular}{|c|c|c|c|c|c|c|}
\hline \multicolumn{7}{|c|}{$\begin{array}{c}\text { Tabel } 6 . \\
\text { Hasil Uji Keberadaan dan Pola Pembentukan Ekspektasi }\end{array}$} \\
\hline Periode & $\gamma_{b}$ & $\gamma_{\mathrm{f}}$ & $\delta$ & J-stat & $\begin{array}{c}\text { Wald- } \\
\text { test } \\
\gamma_{\mathrm{b}}+\gamma_{\mathrm{f}}=1\end{array}$ & $\begin{array}{l}\text { ARCH LM- } \\
\text { test } \\
\left(^{*}\right)\end{array}$ \\
\hline $\begin{array}{l}\text { Full-sample: } \\
(1974.1-2002.4)\end{array}$ & $\begin{array}{r}0.175 \\
(2.357)\end{array}$ & $\begin{array}{l}0.849 \\
(7.160)\end{array}$ & $\begin{array}{c}0.224 \\
(3.159)\end{array}$ & 0.056 & 0.697 & $\begin{array}{c}0.363 \\
(2)\end{array}$ \\
\hline $\begin{array}{l}\text { Sub-sample pre crisis: } \\
(1974.1-1997.2)\end{array}$ & $\begin{array}{c}0.376 \\
(4.984)\end{array}$ & $\begin{array}{l}0.599 \\
(7.471)\end{array}$ & $\begin{array}{c}0.101 \\
(1.500)\end{array}$ & 0.072 & 0.419 & $\begin{array}{c}0.002 \\
(4)\end{array}$ \\
\hline $\begin{array}{l}\text { Sub-sample post crisis: } \\
(1997.3-2002.4)\end{array}$ & $\begin{array}{c}0.357 \\
(5.216)\end{array}$ & $\begin{array}{c}0.536 \\
(7.178)\end{array}$ & $\begin{array}{c}0.116 \\
(1.873)\end{array}$ & 0.260 & 0.002 & $\begin{array}{c}0.418 \\
(4)\end{array}$ \\
\hline \multicolumn{7}{|c|}{$\begin{array}{l}\text { Keterangan: } \\
\text { Angka dalam kurung di bawah masing-masing parameter adalah nilai statistik-t. Statistik-J adalah nilai minimum dari fungsi } \\
\text { objective.Wald-test adalah uji restriksi parameter. ARCH LM-test( }{ }^{*} \text { ) adalah uji residual dengan lag otoregressive antara } 1 \text { sampai } \\
4 \text { periode. Subscipt i merupakan periode lag dari pengaruh output gap (OGHP) pada inflasi, yaitu sekitar } 2 \text { periode. }\end{array}$} \\
\hline
\end{tabular}

\subsubsection{Uji Keberadaan, Pola Pembentukan Ekspektasi, dan Linieritas}

Uji keberadaan, pola pembentukan ekspektasi, dan linieritas Kurva Phillips dilakukan dengan melakukan penaksiran model secara parsial dan keseluruhan:

Model non-linier parsial:

Model 3.a. : $\pi_{t}=\gamma_{b} \pi_{t-1}+\gamma_{f} E_{t}\left\{\pi_{t+1}\right\}+\delta y_{\text {gap t-i }}+\alpha y_{\text {gappos t-j }}$
Model 3.b. : $\pi_{t}=\gamma_{b} \pi_{t-1}+\gamma_{f} E_{t}\left\{\pi_{t+1}\right\}+\delta y_{\text {gap t-i }}+\alpha y_{\text {gapneg t-j }}$

Model non-linier keseluruhan:

Model 3.c. : $\pi_{t}=\gamma_{b} \pi_{t-1}+\gamma_{f} E_{t}\left\{\pi_{t+1}\right\}+\delta y_{\text {gap t-i }}+\alpha_{1} y_{\text {gappos t-j }}+\alpha_{2} y_{\text {gapneg } t-j}$

Adapun hipotesis yang diajukan dalam pengujian linieritas Kurva Phillips pada dasarnya merupakan pengembangan dari hipotesis yang dikemukakan oleh Clark et al. (1995) dan Filardo (1998). Clark et al. mengemukakan bahwa dengan asumsi adanya kendala keterbatasan kapasitas ekonomi (capacity consstraints), maka pengaruh

\footnotetext{
${ }^{13}$ Restriksi jumlah parameter backward looking dan forward looking sama dengan satu (pembentukan ekspektasi bersifat sempurna atau 'penuh') merupakan restriksi yang mengimplikasikan adanya 'vertical long-run Phillips curve', seperti yang dikemukakan dalam hipotesis natural rate. Dalam kaitan ini, dalam jangka panjang, ekspektasi inflasi (yang dibentuk secara sempurna) akan sama dengan inflasi yang terjadi, dan inflasi hanya dibentuk oleh nilai ekpektasinya, bukan oleh output gap, sehingga bentuk Kurva Phillips dalam jangka panjang adalah vertikal.
} 
peningkatan output gap secara signifikan melebihi pengaruh penurunan output gap sehingga Kurva Phillips akan berbentuk konveks. Dengan menggunakan model 3.a ditambah restriksi parameter $\gamma_{b}+\gamma_{f}=1$, Clark et al. menggunakan semacam multiplicative dummy yang berupa variabel output gap positif. Apabila parameter a tidak sama dengan nol, maka secara parsial dapat disimpulkan bahwa Kurva Phillips adalah konveks. Sementara itu, Filardo menganggap perlunya pengujian yang melibatkan semua kondisi ekonomi yang mungkin terjadi, yaitu kontraksi, ekspansi, dan normal. Filardo menggunakan model yang serupa dengan model 3.c, namun pola pembentukan ekspektasi menggunakan asumsi adaptive-partial adjustment.

Dalam penelitian ini pengujian linieritas dilakukan secara bertahap dengan menggunakan ke tiga model, baik parsial maupun keseluruhan. Dalam kaitan ini, "model inti" 3.c dianggap sebagai disain model yang representatif untuk pengujian, karena selain memperhitungkan ketiga kondisi ekonomi yang mungkin terjadi, juga mengakomodir pola pembentukan ekspektasi yang bersifat rational expectation. Berbeda dengan Clark et al., dalam penaksiran ini tidak dilakukan restriksi parameter, tetapi kondisi pakah $\gamma_{b}$ ditambah $\gamma_{f}$ sama dengan satu akan diuji. Selain itu, pengujian linieritas akan dilakukan dengan melihat apakah $\alpha_{1}=\alpha_{2}$, atau $\alpha_{1}+\alpha_{2}=0$.

Dengan metode penaksiran GMM dan variabel instrumental yang sama pada pengujian sebelumnya, yaitu inflasi (lag 1 dan 2), perubahan nilai tukar (lag 0 dan 1), pertumbuhan uang primer (lag 0 dan 1), faktor musiman, dan konstan, hasil penaksiran dirangkum pada tabel-tabel berikut.

Model 7.a.:

Tabel 7.

Hasil Uji Keberadaan, Pola Pembentukan Ekspektasi, dan Linieritas

\begin{tabular}{|c|c|c|c|c|c|c|c|}
\hline Periode & $\gamma_{b}$ & $\gamma_{f}$ & $\delta$ & $\alpha$ & J-stat & $\begin{array}{l}\text { Wald-test } \\
\gamma_{\mathrm{b}}+\gamma_{\mathrm{f}}=1\end{array}$ & $\begin{array}{c}\text { ARCH } \\
\text { LM-test }\left(^{*}\right)\end{array}$ \\
\hline $\begin{array}{l}\text { Full-sample: } \\
(1974.1-2002.4)\end{array}$ & $\begin{array}{r}0.243 \\
(1.808)\end{array}$ & $\begin{array}{r}0.551 \\
(2.470)\end{array}$ & $\begin{array}{r}0.390 \\
(3.057)\end{array}$ & $\begin{array}{r}0.330 \\
(1.943)\end{array}$ & 0.026 & 0.083 & $\begin{array}{r}0.793 \\
(2)\end{array}$ \\
\hline $\begin{array}{l}\text { Sub-sample pre crisis: } \\
(1974.1-1997.2)\end{array}$ & $\begin{array}{r}0.356 \\
(3.809)\end{array}$ & $\begin{array}{r}0.528 \\
(4.907)\end{array}$ & $\begin{array}{r}0.229 \\
(2.174)\end{array}$ & $\begin{array}{c}0.233 \\
(1.956) \\
0.284 \\
(2.053)\end{array}$ & 0.043 & 0.096 & $\begin{array}{r}0.210 \\
(4)\end{array}$ \\
\hline $\begin{array}{l}\text { Sub-sample post crisis: } \\
(1997.3-2002.4)\end{array}$ & $\begin{array}{r}0.336 \\
(3.978)\end{array}$ & $\begin{array}{r}0.439 \\
(4.590)\end{array}$ & $\begin{array}{r}0.150 \\
(1.914)\end{array}$ & $\begin{array}{r}0.370 \\
(1.546)\end{array}$ & 0.233 & 0.011 & $\begin{array}{r}0.165 \\
(1)\end{array}$ \\
\hline
\end{tabular}


Model 7.b.

\begin{tabular}{|c|c|c|c|c|c|c|c|}
\hline Periode & $\gamma_{b}$ & $\gamma_{\mathrm{f}}$ & $\delta$ & $\alpha$ & J-stat & $\begin{array}{c}\text { Wald- } \\
\text { test } \\
\gamma_{\mathrm{b}}+\gamma_{\mathrm{f}}=1\end{array}$ & $\begin{array}{c}\text { ARCH } \\
\text { LM-test } \\
\left(^{*}\right)\end{array}$ \\
\hline $\begin{array}{l}\text { Full-sample: } \\
(1974.1-2002.4)\end{array}$ & $\begin{array}{r}0.231 \\
(2.992)\end{array}$ & $\begin{array}{r}0.520 \\
(3.266)\end{array}$ & $\begin{array}{r}0.503 \\
(2.564)\end{array}$ & $\begin{array}{r}-0.553 \\
(-2.172)\end{array}$ & 0.043 & 0.057 & $\begin{array}{r}0.337 \\
(4)\end{array}$ \\
\hline $\begin{array}{l}\text { Sub-sample pre crisis: } \\
(1974.1-1997.2)\end{array}$ & $\begin{array}{r}0.230 \\
(2.890)\end{array}$ & $\begin{array}{r}0.589 \\
(6.471)\end{array}$ & $\begin{array}{r}0.133 \\
(1.834)\end{array}$ & $\begin{array}{r}-0.182 \\
(-1.441)\end{array}$ & 0.064 & 0.118 & $\begin{array}{r}0.039 \\
(4)\end{array}$ \\
\hline $\begin{array}{l}\text { Sub-sample post crisis: } \\
(1997.3-2002.4)\end{array}$ & $\begin{array}{r}0.278 \\
(3.974)\end{array}$ & $\begin{array}{r}0.434 \\
(3.791)\end{array}$ & $\begin{array}{r}0.724 \\
(5.662)\end{array}$ & $\begin{array}{r}-0.890 \\
(-7.301)\end{array}$ & 0.115 & 0.005 & $\begin{array}{r}0.595 \\
(2)\end{array}$ \\
\hline
\end{tabular}

Model 7.c.:

\begin{tabular}{|c|c|c|c|c|c|c|c|c|}
\hline Periode & $\gamma_{b}$ & $\gamma_{f}$ & $\delta$ & $\alpha_{1}$ & $\alpha_{2}$ & J-stat & $\begin{array}{c}\text { Wald- } \\
\text { test } \\
\gamma_{\mathrm{b}}+\gamma_{\mathrm{f}}=1\end{array}$ & $\begin{array}{c}\text { ARCH } \\
\text { LM-test } \\
\left(^{*}\right)\end{array}$ \\
\hline $\begin{array}{l}\text { Full-sample: } \\
(1974.1-2002.4)\end{array}$ & $\begin{array}{r}0.421 \\
(2.843)\end{array}$ & $\begin{array}{r}0.318 \\
(3.954)\end{array}$ & $\begin{array}{r}0.328 \\
(3.369)\end{array}$ & $\begin{array}{r}0.327 \\
(2.549)\end{array}$ & $\begin{array}{r}-0.274 \\
(-1.943)\end{array}$ & 0.039 & $\begin{array}{l}0.019 \\
0.685\end{array}$ & $\begin{array}{r}0.006 \\
(1)\end{array}$ \\
\hline $\begin{array}{l}\text { Sub-sample pre crisis: } \\
(1974.1-1997.2)\end{array}$ & $\begin{array}{r}0.471 \\
(3.340)\end{array}$ & $\begin{array}{r}0.326 \\
(2.628)\end{array}$ & $\begin{array}{r}0.226 \\
(2.218)\end{array}$ & $\begin{array}{r}0.233 \\
(1.742)\end{array}$ & $\begin{array}{r}-0.166 \\
(-1.411)\end{array}$ & 0.032 & $\begin{array}{l}0.046 \\
0.720\end{array}$ & $\begin{array}{r}0.359 \\
(4)\end{array}$ \\
\hline $\begin{array}{l}\text { Sub-sample post crisis: } \\
(1997.3-2002.4)\end{array}$ & $\begin{array}{r}0.296 \\
(1.341)\end{array}$ & $\begin{array}{r}0.313 \\
(2.907)\end{array}$ & $\begin{array}{r}0.579 \\
(2.698)\end{array}$ & $\begin{array}{r}0.435 \\
(0.855)\end{array}$ & $\begin{array}{r}-0.727 \\
(-2.847)\end{array}$ & 0.089 & $\begin{array}{l}0.012 \\
0.703\end{array}$ & $\begin{array}{r}0.732 \\
(4)\end{array}$ \\
\hline
\end{tabular}

Keterangan:

Angka dalam kurung di bawah masing-masing parameter adalah nilai statistik-t. Statistik-J Statistik-J adalah nilai minimum dari fungsi objective.Wald-test adalah uji restriksi parameter (baris pertama $\gamma_{\mathrm{b}}+\gamma_{\mathrm{f}}=1$ dan baris kedua $\alpha_{1}+\alpha_{2}=0$ ). ARCH LM-test( ${ }^{*}$ ) adalah uji residual dengan lag otoregressive antara 1 sampai 4 periode. Subscipt i merupakan periode lag dari pengaruh output gap (OGHP) pada inflasi, yaitu sekitar 2 periode. Subscipt j merupakan periode lag dari pengaruh output gap positif /negatif (OGHP) pada inflasi, yaitu berkisar antara 1 sampai 4 periode.

Berdasarkan hasil penaksiran pada tabel tersebut dapat dilihat bahwa secara keseluruhan model dapat menjelaskan perilaku Kurva Phillips versi baru dengan parameter linieritas. Hasil penaksiran model parsial 3.a dan 3.b masing-masing menunjukkan adanya non-linieritas parsial konveks dan konkav. Namun, dari penaksiran "model inti" dapat dilihat bahwa, walaupun secara parametrik terdapat perbedaan nilai antara $\alpha_{1}$ dan $\alpha_{2}$, hasil uji restriksi parameter menolak hipotesis bahwa $\alpha_{1}+\alpha_{2}=0$. Hal tersebut menyimpulkan bahwa secara statistik, non-linieritas dalam Kurva Phillips tidak terbukti.

Secara keseluruhan (full sample), baik parameter backward maupun forward looking dan output gap (0.33) sangat signifikan secara statistik. Terlihat bahwa, berdasarkan struktur 
model di atas, nilai $g_{f}$ secara relatif lebih kecil dari $\gamma_{b}$,yang mengindikasikan adanya dominasi Kuva Phillips tradisional yang backward looking dalam menjelaskan proses inflasi. Lebih jauh, dari hasil tersebut dapat dilihat pula bahwa, seperti halnya hasil pada pengujian hipotesis tradisional, pengaruh output gap terhadap inflasi mengalami perubahan signifikan, yaitu dari 0.23 pada periode sebelum krisis menjadi 0.58 pada periode pasca krisis. Secara keseluruhan, hasil tersebut menyimpulkan bahwa keberadaan non-linieritas dalam Kurva Phillips kurang terbukti secara kuat.

\subsubsection{Hasil Uji dengan Menggunakan Model Time-Varying Parameter}

Beberapa temuan seperti disampaikan di atas cukup menarik, paling tidak dikarenakan oleh dua hal. Pertama, berbeda dengan hasil penaksiran model hybrid yang menunjukkan dominasi pola pembentukan ekspektasi forward looking (New Keynesian model), penaksiran "model inti" menunjukkan hasil yang relatif berlawanan. Hasil tersebut sejalan dengan kajian Rudd dan Whelan (2001), yang menyatakan bahwa penaksiran model hybrid oleh Gali dan Gertler (1999) dengan menggunakan GMM yang melibatkan penggunaan variabel instrumental mempunyai potensi penaksiran $\gamma_{f}$ yang bias upward, sepanjang $\pi_{t+1}$ dan variabel yang digunakan sebagai variabel instrumental sama-sama berkorelasi dengan variabel yang (seharusnya) diperhitungkan dalam stuktrur model yang sebenarnya (true model), namun tidak diabaikan dalam penaksiran. Dari penaksiran "model inti" yang melibatkan kemungkinan adanya pengaruh tekanan pada non-linieritas, paling tidak nilai $\gamma_{f}$ berkurang secara signifikan, dan bahkan mendukung peranan pola pembentukan ekspektasi backward looking dalam menjelaskan proses inflasi.

Kedua, hasil penaksiran "model inti" dengan menggunakan prosedur standar GMM belum dapat menangkap fenomena non-linearity secara kuat, walaupun terdapat indikasi mengenai hal tersebut. Untuk itu, perlu dilakukan penaksiran model tersebut dengan menggunakan metode penaksiran alternatif yang dapat menangkap kecenderungan perubahan struktur perekonomian yang dikaitkan dengan adanya unsur ketidakpastian (uncertainty), yang tercermin pada perubahan pola keterkaitan dalam Kurva Phillips. Secara khusus, unsur ketidakpastian tersebut terkandung pada nilai taksir dari output gap. Untuk itu, dalam teknik pengujian berikutnya, disusun premis bahwa adanya unsur uncertainty pada perkembangan output-gap menyebabkan perubahan parameter model.

Dengan demikian, model hipotesis yang akan ditaksir adalah "model inti" yang ditransformasikan ke dalam bentuk model State Space - Time-Varying Parameter sebagai berikut. 


$$
\begin{aligned}
& \pi_{t}=\ldots+\left(\delta_{c}+\delta_{t}\right) y_{\text {gap t-i }}+\ldots \ldots \\
& \delta_{t}=\rho \delta_{t-1}
\end{aligned}
$$

Dalam kaitan ini, dianggap bahwa pengaruh output gap terhadap inflasi dicerminkan oleh dua parameter, yaitu parameter yang bersifat konstan (fixed sparameter, $\delta_{c}$ ) dan parameter yang bersifat variatif/random dengan perilaku tertentu (varying parameter, $\delta_{t}$ ), yang dalam penaksiran model kali ini diasumsikan mempunyai pengaruh diri dengan proses otoregresif derajat satu. Adapun metode penaksiran yang umum digunakan adalah Maximum Likelihood Estimation (MLE) dengan algoritma Kalman Filter. ${ }^{14}$ Selanjutnya, keberadaan $\mathrm{p}_{\mathrm{t}+1}$ ditaksir secara recursive dengan sederet variabel instrumental yang sama dengan penaksiran-penaksiran sebelumnya. Hasil penaksiran model dirangkum sebagai

\begin{tabular}{|c|c|c|c|c|c|c|c|c|c|}
\hline & \multirow{2}{*}{$\gamma_{b}$} & \multirow{2}{*}{$\gamma_{f}$} & \multirow{2}{*}{$\delta_{c}$} & $\operatorname{SD}\left(\delta_{t}\right)$ & \multirow{2}{*}{$\rho$} & \multirow{2}{*}{$\alpha_{1}$} & \multirow{2}{*}{$\alpha_{2}$} & \multirow{2}{*}{ LL } & \multirow{2}{*}{$\begin{array}{c}\text { Wald- } \\
\text { test } \\
\gamma_{b}+\gamma_{f}=1 \\
\alpha_{1}+\alpha_{2}=0\end{array}$} \\
\hline & & & & Final $\delta_{t}$ & & & & & \\
\hline Full sample: & 0.549 & 0.172 & 0.277 & 0.130 & -0.999 & 0.242 & -0.242 & 257.43 & 0.000 \\
\hline $1974.1-2002.4$ & $(14.30)$ & (3.210) & (4.495) & -0.155 & $(-295.4)$ & $(3.757)$ & $(-2.907)$ & & 0.998 \\
\hline \multirow[t]{2}{*}{$1974.1-1997.2$} & 0.417 & 0.421 & 0.083 & 0.109 & -1.011 & 0.014 & -0.105 & 235.60 & 0.015 \\
\hline & $(7.243)$ & $(5.497)$ & (1.292) & -0.162 & $(-139.8)$ & $(0.291)$ & $(-0.752)$ & & 0.554 \\
\hline \multirow[t]{2}{*}{$1997.3-2002.4$} & 0.144 & 0.807 & 0.785 & 0.194 & -0.799 & 1.574 & -0.660 & 36.65 & 0.770 \\
\hline & $(0.864)$ & (3.375) & $(5.092)$ & -0.016 & $(-3.062)$ & (7.087) & $(-5.433)$ & & 0.000 \\
\hline
\end{tabular}
berikut.

Dari tabel tersebut dapat dilihat bahwa secara keseluruhan model dapat menjelaskan perilaku Kurva Phillips versi baru dengan parameter linieritas. Beberapa temuan utama yang dapat disimpulkan adalah sebagai berikut. Pertama, seperti halnya hasil pada pengujian hipotesis tradisional dan model 3 pengaruh output gap terhadap inflasi mengalami

\footnotetext{
${ }^{14}$ Secara umum, Kalman Filter adalah algoritma rekursif untuk penaksiran the one-step ahead secara sekuensial dari nilai rata-rata dan varians state variables dengan mendasarkan informasi baru. Secara teknis, dengan mendasarkan pada nilai awal (initial values) dari nilai rata dan kovarians dari state variables, serta nilai dari parameters lain dalam sistem, dilakukan penaksiran one-step ahead dari nilai state variables beserta mean-squared errors-nya. Hasil tersebut selanjutnya digunakan untuk mengevaluasi nilai gaussian log likelihood dan sekaligus menentukan set dari nilai parameter selanjutnya. Pengitungan tersebut dilakukan secara iteratif hingga mencapai konvergensi.
} 
peningkatan signifikan pada periode pasca krisis. Secara keseluruhan, nilai taksiran parameter konstan dari pengaruh output gap dengan memperhitungkan variasinya (standar deviasi dari parameter random) relatif dapat diperbandingkan (comparable) dengan nilai taksir parameter pada model-model sebelumnya. Kedua, baik parameter backward maupun forward looking dan output gap signifikan secara statistik. Terlihat bahwa, secara keseluruhan, nilai $\gamma_{f}$ secara relatif lebih kecil dari $\gamma_{b}$ yang mengindikasikan adanya dominasi Kuva Phillips tradisional yang backward looking dalam menjelaskan proses inflasi. Namun, hasil penaksiran pada sub-sampel menunjukkan bahwa pada periode pasca krisis, pola pembentukan ekspektasi forward looking lebih dominan dibadingkan dengan pola pembentukan ekspektasi backward looking. Ketiga, berbeda dengan hasil penaksiran sebelumnya, pada periode pasca krisis hasil uji restriksi parameter menolak hipotesis bahwa $\alpha_{1}+\alpha_{2}=0$. Hasil ini menyimpulkan bahwa non-linieritas Kurva Phillips secara signifikan terdeteksi pada periode pasca krisis.

\section{Kesimpulan dan Implikasi Kebijakan}

Dari hasil penaksiran dan pengujian model empiris, diperoleh beberapa temuan penting, antara lain dapat disimpulkan bahwa fenomena Kurva Phillips eksis dalam perekonomian Indonesia, dimanakeberadaan dan perilaku kurva tersebut mengalami perubahan dari waktu ke waktu, sejalan dengan perubahan struktur fundamental perekonomian (regime dependent), khususnya sebagai akibat dari krisis ekonomi 1997. Secara khusus, pola pembentukan ekspektasi dan linieritas dalam Kurva Phillips mengalami perbedaan (perubahan) yang signifikan antara periode pre dan pasca krisis. Karakteristik Kurva Phillips pada periode pre krisis adalah: (i) pengaruh tekanan output gap pada

Grafik 6.

Karakteristik Kurva Phillips di Indonesia

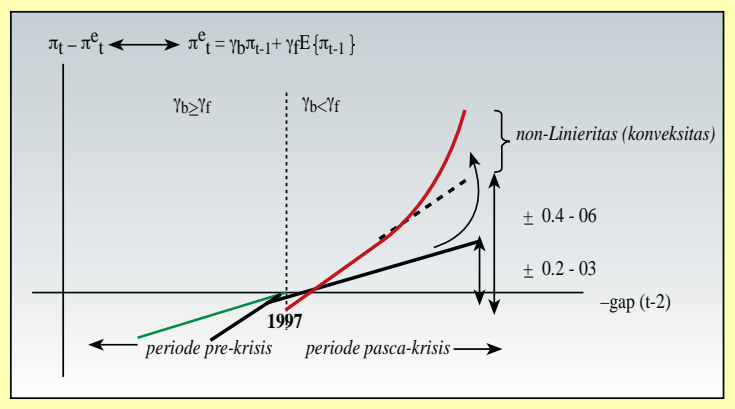




\begin{tabular}{|c|c|c|c|c|}
\hline \multicolumn{5}{|c|}{$\begin{array}{c}\text { Tabel 9. } \\
\text { Perbadingan hasil Studi Kurva Phillips di Beberapa Negara }\end{array}$} \\
\hline Negara & $\begin{array}{c}\text { Keberadaan } \\
\text { ( parameter OG) }\end{array}$ & $\begin{array}{c}\text { Pola Pembentukan } \\
\text { Ekspektasi }\end{array}$ & $\begin{array}{c}\text { Linieritas } \\
\text { (kesimetrisan) }\end{array}$ & $\begin{array}{c}\text { Time Frame } \\
\text { (periode obesrvasi) }\end{array}$ \\
\hline $\begin{array}{c}\text { Thailand } \\
\text { (Banthumnavin, 2002) }\end{array}$ & $\begin{array}{l}0.04-0.05 \\
(\operatorname{lag} 2-3)\end{array}$ & $\begin{array}{c}\text { spesifikasi } \\
\text { backward looking }\end{array}$ & $\begin{array}{l}\text { spesifikasi } \\
\text { linier }\end{array}$ & $\begin{array}{c}\text { teridentifikasi pada } \\
\text { pasca krisis } 1997\end{array}$ \\
\hline $\begin{array}{c}\text { Colombia } \\
\text { (Julio \& Gomez, 2000) }\end{array}$ & $\begin{array}{c}0.2-0.4 \\
(\operatorname{lag} 1-3)\end{array}$ & $\begin{array}{c}\text { spesifikasi } \\
\text { backward looking }\end{array}$ & $\begin{array}{l}\text { spesifikasi } \\
\text { linier }\end{array}$ & $\begin{array}{c}\text { tidak termasuk } \\
\text { periode resesi } 1999\end{array}$ \\
\hline $\begin{array}{c}\text { Spanyol } \\
\text { (salido \& Gali, 2001) }\end{array}$ & $\begin{array}{c}0.4-0.5 \\
(\mathrm{MC} \operatorname{lag} 0)\end{array}$ & $\begin{array}{c}\text { spesifikasi } \\
\text { forward looking }\end{array}$ & $\begin{array}{l}\text { spesifikasi } \\
\text { linier }\end{array}$ & $\begin{array}{l}\text { periode disinflation } \\
1980-1998\end{array}$ \\
\hline $\begin{array}{l}\text { Selandia Baru } \\
\text { (Razzak, 1997) }\end{array}$ & $\begin{array}{c}0.1-0.2 \\
(\log 3) \\
\end{array}$ & $\begin{array}{c}\text { spesifikasi } \\
\text { forward looking }\end{array}$ & $\begin{array}{l}\text { konveks } \\
\text { asimetris }\end{array}$ & periode 1983 - 1994 \\
\hline $\begin{array}{c}\text { USA } \\
\text { (Clark et al., 1995) } \\
\end{array}$ & $\begin{array}{c}0.2-0.4 \\
(\operatorname{lag} 0) \\
\end{array}$ & $\begin{array}{l}\text { spesifikasi backward } \\
\text { forward looking }\end{array}$ & $\begin{array}{l}\text { konveks } \\
\text { asimetris }\end{array}$ & periode 1964 - 1990 \\
\hline $\begin{array}{c}\text { Indonesia } \\
\text { (Solikin, 2003) }\end{array}$ & $\begin{array}{c}\text { pre krisis: } 0.2-0.3 \\
\text { pasca krisis: } 0.4-0.6 \\
(\operatorname{lag} 2)\end{array}$ & $\begin{array}{l}\text { spesifikasi backward } \\
\text { forward looking }\end{array}$ & $\begin{array}{l}\text { konveks } \\
\text { asimetris }\end{array}$ & periode 1974 - 2002 \\
\hline
\end{tabular}

perkembangan inflasi cenderung moderat $(0.2-0.3)$, (ii) dominasi pola pembentukan ekspektasi backward dan forward looking relatif seimbang, dan (iii) pola hubungan cenderung bersifat linier. Sementara itu, karakteristik Kurva Phillips pada periode pre krisis adalah: (i) pengaruh tekanan output gap pada perkembangan inflasi cenderung meningkat $(0.4-0.6)$, (ii) adanya dominasi pola pembentukan ekspektasi forward looking, dan (iii) pola hubungan cenderung bersifat non-linier (konveks). Secara ilustratif, karakteristik tersebut dapat digambarkan pada grafik 6.

Perlu dikemukakan bahwa beberapa temuan dalam kajian ini mempunyai kesamaan relevansi dari keberadaan Kurva Phillips, baik di negara maju maupun berkembang. Perbandingan hasil studi Kurva Phillips di beberapa negara disampaikan pada tabel 9.

Relevansi dari beberapa temuan tersebut di atas cukup signifikan dengan mengingat karakteristik dan perubahn struktural perekonominan Indonesia, terutama setalah terjadinya krisis ekonomi 1997. Beberapa implikasi penting yang perlu diperhatikan berkaitan dengan upaya penyusunan kerangka strategis kebijakan moneter yang terarah antara lain dapat dikemukakan sebagai berikut.

a. Pertama, semakin kuatnya pengaruh tekanan ekonomi, yang tercermin pada perkembangan output gap, pada perkembangan inflasi pada periode pasca krisis menunjukkan semakin pentingnya peranan pertumbuhan ekonomi sebagai salah satu indikator pencapaian sasaran akhir kebijakan makro-moneter. Hal ini, terutama dengan 
memperhitungkan lag pengaruh output gap terhdap inflasi yang cukup pendek, yaitu sekitar 2 (dua) triwulan. Selain itu, peningkatan sensitivitas inflasi terhadap perkembangan output sejalan dengan fenomena perkembangan output-harga, dan secara tidak langsung menunjukkan bahwa pada periode pasca krisis terjadi penurunan rigiditas perkembangan harga. Kedua fakta empiris tersebut merupakan landasan yang penting yang harus diperhatikan dalam perumusan kerangka kebijakan moneter dewasa ini yang didasarkan pada pencapaian sasaran tunggal stabilitas harga.

b. Kedua, peranan pola pembentukan ekspektasi forward looking yang cukup dominan disamping backward looking merupakan salah pencerminan terhadap persepsi pelaku ekonomi yang cenderung memperkirakan akan tetap tingginya (potensi) tekanan inflasi di masa-masa yang akan datang. Hal ini sejalan dengan sangat tingginya derajat persistensi dan ketidakpatian dalam perkembangan output dan harga di Indonesia. ${ }^{15}$ Berkaitan dengan fakta empiris tersebut, maka efektivitas pencapaian sasaran akhir kebijakan moneter dengan sasaran tunggal stabilitas harga akan sangat bergantung pada sejauhmana komitmen (kredibilitas) bank sentral dalam mengupayakan perkembangan inflasi yang rendah dan stabil dalam kurun waktu tertentu. Selain itu, kebijakan moneter sebaiknya dilakukan dengan lebih konsisten (jelas arah) dan mengurangi unsur akomodatif. Hal ini berkaitan dengan cukup besarnya "biaya ketidakpastian" dalam pelaksanaan kebijakan moneter. Sejalan dengan hal-hal tersebut, rencana penerapan kerangka kerja kebijakan moneter Inflation Targeting perlu dilihat sebagai wahana untuk meningkatkan kredibilitas (dan komitmen) bank sentral sehingga hal tersebut dapat mengatasi permasalahan "persistent inflationary bias" dan mengurangi biaya pengendalian inflasi.

c. Ketiga, kecendurungan perubahan keterkaitan perkembangan output dan harga pada periode krisis, yang tercermin pada non-linieritas (asimetri) Kurva Phillips sejalan dengan hipotesis mengenai adanya "capacity constraints", terutama pada periode krisis. Lebih lanjut, hal tersebut juga mengimplikasikan perlunya perumusan kebijakan yang memperhitungkan stage dimana kondisi perekonomian sedang berada. Hal ini terkait dengan adanya kecenderungan penurunan/peningkatan biaya pengendalian inflasi (cost of fighting inflation, i.e. sacrifice ratio). Oleh karena itu, perlu pula penetapan prioritas pertumbuhan ekonomi atau penurunan inflasi.

\footnotetext{
${ }^{15}$ Pernyataan ini juga didukung oleh hasil pengujian persistensi dan volatilitas perkembangan variabel output dan harga pada bagian lain dari paper penelitian selengkapnya.
} 


\section{Catatan Penutup}

Di luar beberapa temuan di atas, perlu dikemukakan bahwa pendekatan yang digunakan dalam penelitian ini lebih bersifat parsial, dalam artian bahwa penilaian dan pengujian hanya ditujukan pada relevansi permasalahan yang diajukan. Menghadapi kendala keterbatasan (ketersediaan) dan pengolahan data, serta keunikan struktur perekonomian Indonesia, maka diperlukan suatu kewaspadaan/reservasi dalam menginterpretasikan "magnitude" parameter permodelan, terutama pola pembentukan ekspektasi, baik backward maupun forward looking. Dalam kaitan ini, perlu ditekankan bahwa sesuai dengan asumsi awal yang telah diuraikan, keberadaan pola pembentukan ekspektasi forward looking bersama-sama dengan backward looking pada dasarnya bersifat inheren dalam permodelan. Secara signifikan, pengujian model empiris menyimpulkan bahwa keberadaan kedua pola pembentukan ekspektasi tersebut sama-sama valid untuk kasus Indonesia, terlepas hasil interpretasi "magnitude" parameter yang masih dapat diperdebatkan.

Selain itu, juga disadari akan perlunya penggunaan kerangka pengkajian alternatif, atau bahkan pengembangan kerangka permodelan yang lebih realistis. Hal tersebut terutama terkait dengan fakta bahwa sebagai salah satu aspek strategis dalam bidang kajian kebijakan, khususnya kebijakan moneter, keterkaitan perkembangan output dan harga akan senantiasa menjadi suatu topik kajian yang layak untuk dicermati.

Penelitian dengan hasil yang telah disampaikan di atas pada dasarnya merupakan suatu penelitian awal. Dalam penelitian ini, belum dikaji bagaimana perilaku keterkaitan output dan harga dalam perspektif perkembangan atau domain waktu - baik dalam jangka pendek, maupun menengah/panjang, terutama dikaitkan dengan repons kebijakan moneter oleh bank sentral. Berkaitan dengan penyusunan kerangka kebijakan moneter yang berlangsung saat ini, topik lanjutan tersebut tentunya merupakan suatu yang penting untuk dilakukan selanjutnya. 


\section{DAFTAR PUSTAKA}

Chada, B. and E. Prasad, Interpreting the Cyclical Behavior of Prices, IMF Staff Papers, 40 (1993), 266-298.

Clark, Peter, et al., Asymmetry in the US Output-Inflation Nexus: Issues and Evidence, IMF Staff Papers No.43, 1996.

Cooley, T.F. and L.E. Ohanian, The Cyclical Behavior of Prices, Journal of Monetary Economics, 28 (1991), 25-60.

Debelle. Guy and Douglas Laxton, Is the Phillips Curve Really a Curve?: Some Evidence for Canda, the United Kingdom, and the United States, IMF Working Paper, No. 111, October 1996.

Engle, Robert F., Estimates of the variance of U.S. Inflation based upon the ARCH Model, Journal of Money, Credit, and Banking, Vol. 15, August 1983.

Filardo, Andrew J., New Evidence on the Output Cost of Fighting Inflation, FRB Kansas City, 1998.

Foster, Edward, The Variability of Inflation, The Review of Economics and Statistics, Vol. 60, August 1978.

Fuhrer, Jeff and George Moore, Inflation Persistence, the Quarterly Journal of Economics, Vo. 110, Issue 1, February 1995.

Gagnon, J.E., Inflation Regimes and Inflation Expectations, International Discussion Papers

No. 581, Board of Governors of the Federal Reserve System, May 1997.

Gali, Jordi, and Mark Gertler, Inflation Dynamics: A Structural Econometric Analysis, NBER Working Paper No. 7551,Februari 2000.

Gali, Jordi and Lopez-Salido, J.D., A New Phillips Curve for Spain, BIS Paper No. 3, 2000. Hann, Wouter J. den, The Comovement between Output and Prices, Journal of Monetary Economics, 46 (2000), 3-30.

Judd, John P. and Trehan, Barat, The Cyclical Behavior of Prices: Interpreting the Evidence, Journal of Money, Credit, and Banking, 27 (1995), 789-797.

Katsimbris, G.M., The Relationship between the Inflation Rate, Its variability, and Output Growth Variability: Disaggregated International Evidence, Journal of Money, Credit, and Banking, Vol. 17, May 1985.

King, R.G., C.I. Plosser, J.H. Stock, and M.W.Watson, Stochastic Trends and Economic Fluctuations, American Economic Review, 81 (1991), 819-840.

Laxton, Douglas, et al., Asymmetric Effects of Economic Activity on Inflation: Evidence and 
Policy Implications, IMF Staff Papers No. 42, 1995.

Pagan, A., A.D. Hall, and P.K. Trivedi, Assessing the Variability of Inflation, The Review of Economic Studies, Vol. 50, October 1983.

Roberts, John M., New Keynessian Economics and the Phillips Curve, Journal ofMoney, Credit, and Banking, Vo. 27, Issue 4, November 1995.

Rotemberg, J.J., Prices, Output, and Hours: an Empirical Analysis based on a Sticky Price Model, Journal of Monetary Economics, 37 (1996), 505-534.

Rudd, J. and Karl Whelan, New Tests of the New-keynesian Phillips Curve, Federal Reserve Board, 2001.

Schaling, Eric, The Non-Linear Phillips Curve and Inflation Forecast Targeting, Bank of England, London, 1999.

Solikin dan Reza A., Penaksiran Kesenjangan Output dalam rangka Mengantisipasi Perkembangan Inflasi, Occasional Paper Bank Indonesia, Direktorat Riset Ekononomi dan Kebijakan Moneter, 1999 
Halaman ini sengaja di kosongkan 